\title{
WestVirginiaUniversity
}

THE RESEARCH REPOSITORY @ WVU

West Virginia Agricultural and Forestry Experiment

Davis College of Agriculture, Natural Resources

Station Bulletins

And Design

$1-1-1917$

\section{Certain Characteristics of Hen Eggs}

Horace Atwood

Charles Edward Weakley

Follow this and additional works at: https://researchrepository.wvu.edu/ wv_agricultural_and_forestry_experiment_station_bulletins

\section{Digital Commons Citation}

Atwood, Horace and Weakley, Charles Edward, "Certain Characteristics of Hen Eggs" (1917). West Virginia Agricultural and Forestry Experiment Station Bulletins. 166.

https://researchrepository.wvu.edu/wv_agricultural_and_forestry_experiment_station_bulletins/166

This Bulletin is brought to you for free and open access by the Davis College of Agriculture, Natural Resources And Design at The Research Repository @ WVU. It has been accepted for inclusion in West Virginia Agricultural and Forestry Experiment Station Bulletins by an authorized administrator of

The Research Repository @ WVU. For more information, please contact ian.harmon@mail.wvu.edu. 
West Virginia University Libraries

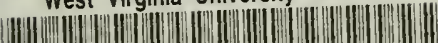

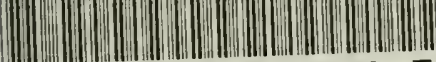

308021007621097 



\section{Tatest Virquinia anibersity Agricultural Experiment Station MORGANTOWN}

DEPARTMENT OF POULTRY HUSBANDRY

Certain Characteristics of HenEggs

TECHNICAL BULLETIN

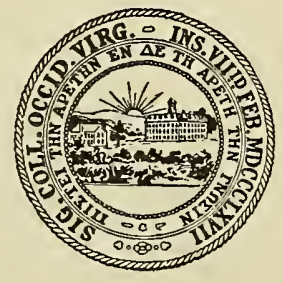

BY

Horace Atwood and Chas. E. Weakley, Jr.

Eulletins and Reports of this Station will be mailed free to any citizen of West Virginia npon written application. Address Director of the West Virginia Agricultural Experiment Station, Iorgantown, W. Va. 


\section{THE STATE OF WEST VIRGINIA}

\section{Educational Institutions}

\section{THE STATE BOARD OF CONTROL}

E. B. STEPHENSON, President _-______________-_Charleston, W. Va. JAMIES S. LAKIN

Charleston, W. Va. J. M. WILLIAMSON

Charleston, W. Va.

The State Board of Control has the direction of the financial and business affairs of the state educational institutions.

\section{THE STATE BOARD OF REGENTS}

M. P. SHAWKEY, President State Superintendent of Schools

GEORGE S. LAIDLEY

Charleston, W. Va.

NOAH G. KEIM

EARL W. OGLEBAY

JOSEPH M. MURPHY

Charleston, W. Va. Elkins, W. Va. -Wheeling, W. Va.

The State Board of Regents has charge of all matters of purelyg, W. Va. nature concerning the state educational institutions.

\section{WEST VIRGINIA UNIVERSITY}

FRANK BUTLER TROTTER, LL.D

President

\section{Agricultural Experiment Station Staff}

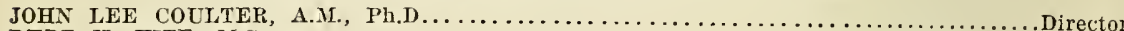

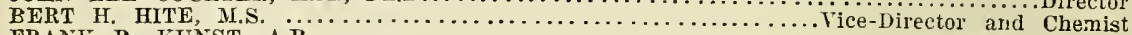

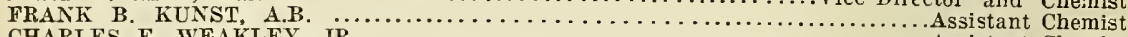

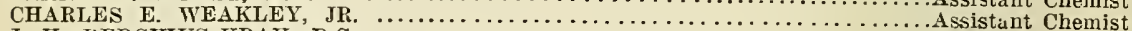

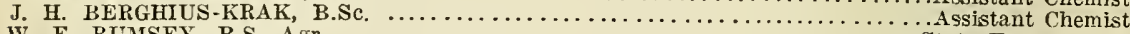

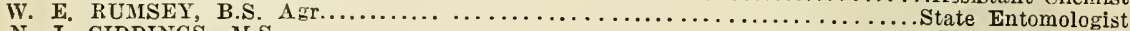

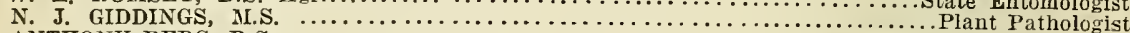

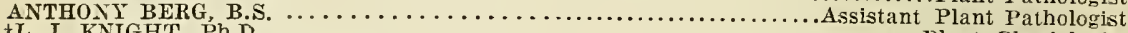

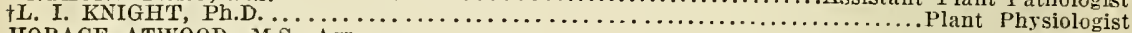

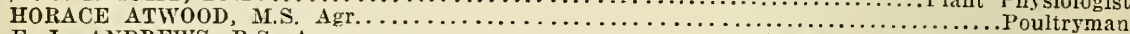

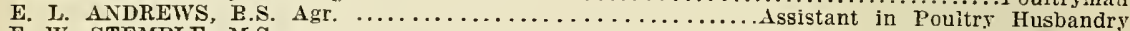

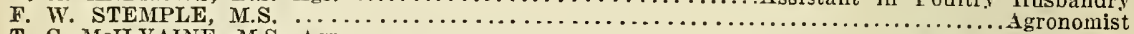

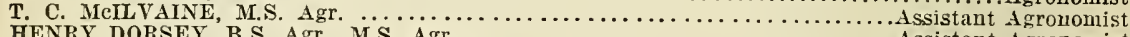

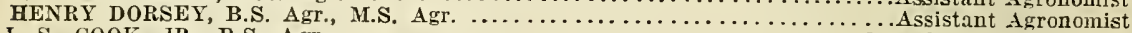

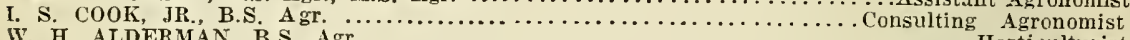

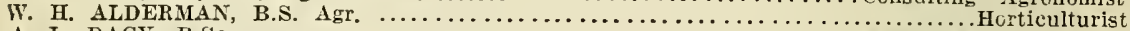

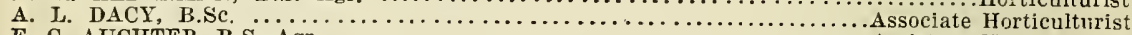

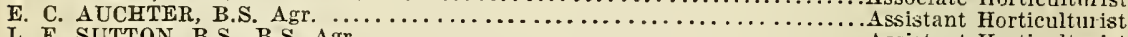

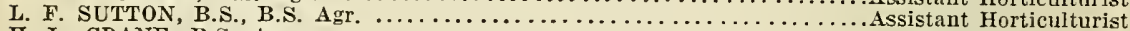

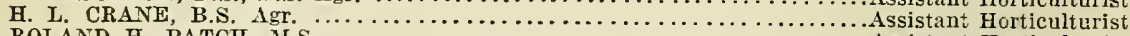

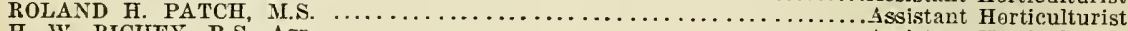

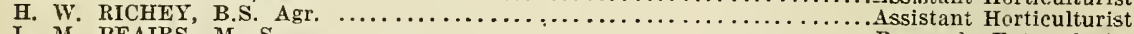

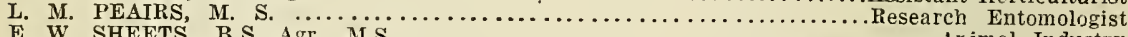

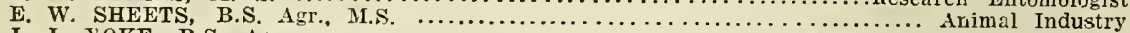

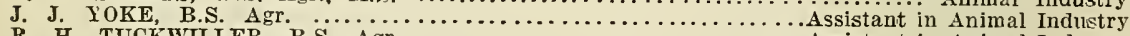

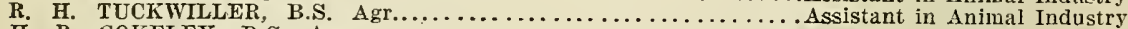

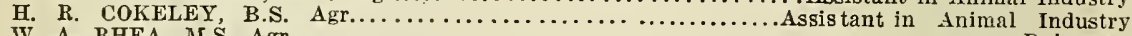

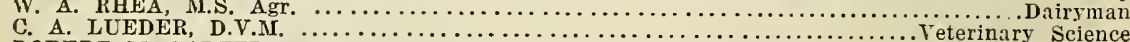

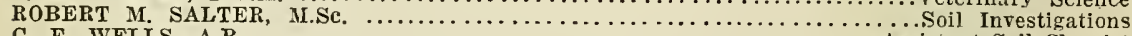

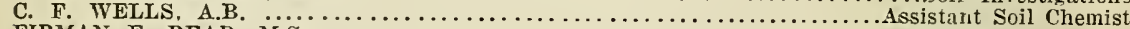

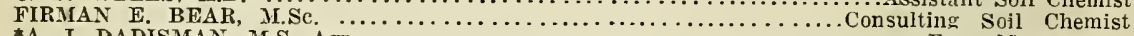

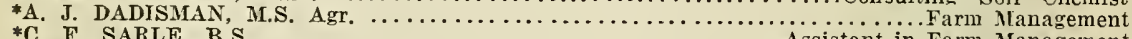

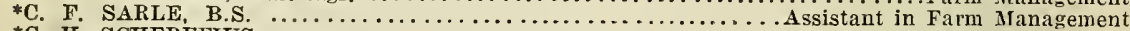

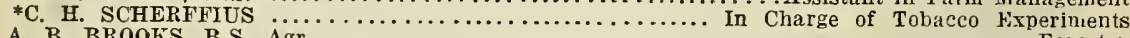

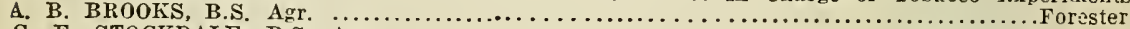

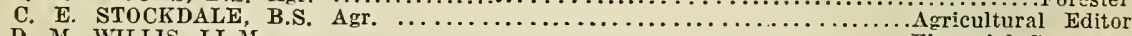

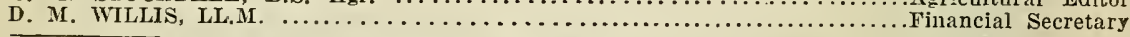

In co-operation with the University of Chicago.

*In co-operation with the U. S. Department of Agrieulture. 


\section{CERTAIN CHARACTERISTICS OF HEN EGGS}

BY HORACE ATWOOD and CHAS. E. WEAKLEY, Jr.

\section{INTRODUCTION.}

It is not unusual for chicks hatched by the same hen or in the same incubator to differ with respect to vigor. Some of them may be strong, thrifty, and have the ability to make a rapid growth when properly brooded and fed; while others may lack that robustness of constitution which is essential to normal development.

The eggs from which the chicks are hatched must be responsible for these easily observable and oftentimes pronounced differences, and the question arises whether eggs have any physical characteristics which may be correlated in any way with these differences in vigor.

In order to begin the study of this subject, the work on eggs reported in this bulletin has been carried out. So far no effort has been made to correlate the observed differences existing among eggs with the vigor of the resulting chickens, but the senior author has already pointed out that small eggs produce small chicks which have a high mortality and a slow growth.*

The investigations herein described were begun in January, 1915. Two pens of single comb White Leghorn pullets were selected and placed in two colony laying houses of similar type. Each pen consisted of twenty females and one male selected with respect to uniformity of age, breeding, and appearance.

During the first year the fowls were fed as follows: Pen 1 received cracked corn scattered in litter, together with a dry mash consisting of 90 percent corn meal and 10 percent beef scrap. This mash was fed in a hopper to which the fowls had constant access. Pen 2 received whole wheat scattered in litter together with hopper-fed mash consisting of 45 percent wheat bran, 45 percent wheat middlings, and 
10 per cent beef scrap. Both lots were supplied, as is customary, with water, grit, oyster shell, green food, and charcoal. Each house was provided with two small runs which were alternately sown to rye and oats so as to provide the fowls with green food in season.

During the second year, the fowls were fed as previously described except that the amount of beef scrap in the mash was doubled. This increase in the amount of beef scrap was made in order to bring about a better egg production since the original ration lacked variety and seemed to be somewhat unpalatable. The mortality among the corn fed fowls was very low, but several of the wheat fed fowls died apparently from digestive troubles.

The fowls were trap nested and the eggs were examined by the junior author on the day following that on which they were laid. This examination consisted first in weighing the eggs as received at the chemical laboratory. Then each egg was opened and the yolk transferred to a piece of filter paper so as to absorb any trace of white which might adhere to it. The weight of the yolk was then determined at once. This method was found to be more satisfactory than that of separating the parts after boiling.

In the discussion of the results, the weights of the eggs and yolks examined in 1915 and in 1916 will first be considered; then the influence of the egg cycles on egg and yolk weight will be taken up; and finally the studies of the egg production of individual hens will be discussed.

\section{INFLUENCE OF RATION ON WEIGHT OF EGG AND RELATIVE WEIGHT OF YOLK.}

\section{Results for 1915.}

Table I which follows shows the number and average weight in grams of the eggs which were examined during 1915, arranged and averaged according to weeks. Table II shows the number and average weight of the yolks of the eggs which were examined during 1915, arranged and averaged according to weeks. Table III was derived from Tables I and II and shows what percentage of the eggs was yolk. Table IV classifies the eggs of Pen 1 according to weight and gives the percent yolk. Table $\mathrm{V}$ classifies the eggs of Pen 2 according to weight and gives the percent yolk. 
TABLE I.-Average Weight and Number of Eggs Obtained From Pens 1 and 2 During 1915.

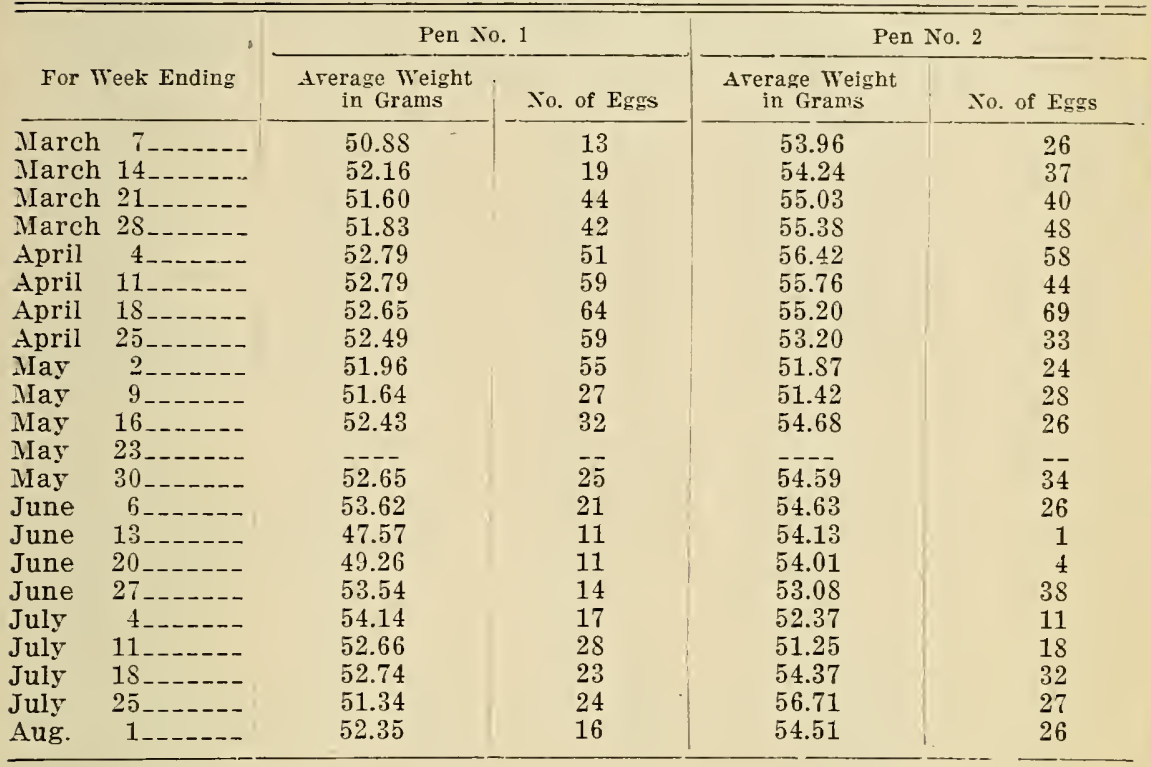

TABLE 11.-Average Weight of Yolks Obtained From Pens 1 and 2 During 1915.

\begin{tabular}{|c|c|c|c|c|c|}
\hline \multirow{2}{*}{\multicolumn{2}{|c|}{ For Week Ending }} & \multicolumn{2}{|c|}{ Pen No. 1} & \multicolumn{2}{|c|}{ Pen No. 2} \\
\hline & & $\begin{array}{l}\text { Average Weight } \\
\text { in (irams }\end{array}$ & No. of Yolks & $\begin{array}{l}\text { Average Weight } \\
\text { in Grams }\end{array}$ & No. of Yolks \\
\hline March & $7 \ldots$ & 15.28 & 13 & 16.22 & 26 \\
\hline March & $14 \ldots \ldots$ & 15.44 & 19 & 16.00 & 37 \\
\hline March & $21 \ldots \ldots$ & 15.90 & 44 & 16.33 & 40 \\
\hline March & 28 & 16.09 & 42 & 16.45 & 48 \\
\hline April & 4 & 16.08 & 51 & 16.79 & $5 S$ \\
\hline April & $11 \ldots \ldots$ & 15.83 & 59 & 16.70 & 44 \\
\hline April & 18 & 15.73 & 64 & 16.06 & 69 \\
\hline April & $25 \ldots \ldots \ldots$ & 15.72 & 59 & 16.15 & 33 \\
\hline May & 2 & 15.63 & 55 & 15.36 & 24 \\
\hline May & $9 \ldots$ & 15.28 & 27 & 14.87 & $2 s$ \\
\hline May & $16 \ldots$ & 15.48 & 32 & 16.06 & 26 \\
\hline May & $23 \ldots \ldots$ & $-=--$ & $-=$ & $-1-$ & $\overrightarrow{-l}$ \\
\hline May & 30 & 15.47 & 25 & 16.03 & 34 \\
\hline June & 6 & 16.45 & 21 & 15.90 & 26 \\
\hline June & $13 \ldots \ldots$ & 14.89 & 11 & 16.34 & 1. \\
\hline June & $20 \ldots$ & 15.47 & 11 & 14.88 & 4 \\
\hline June & $27 \ldots \ldots-\cdots$ & 16.47 & 14 & 16.33 & 38 \\
\hline July & 4 & 16.42 & 17 & 16.45 & 11 \\
\hline July & $11 \ldots \ldots$ & 16.02 & 28 & 15.00 & is \\
\hline July & $18 \ldots$ & 16.06 & 23 & 16.19 & 32 \\
\hline July & $25---\cdots--$ & 15.67 & 24 & 16.72 & 27 \\
\hline Aug. & $1 \ldots \ldots$ & 16.50 & 16 & 16.95 & 26 \\
\hline
\end{tabular}


W. VA. AGR'L EXPERIMENT STATION [Bulletin 166

TABLE III.-Average Percentage of Yolk in Eggs Obtained from Pens 1 and 2 During 1915.

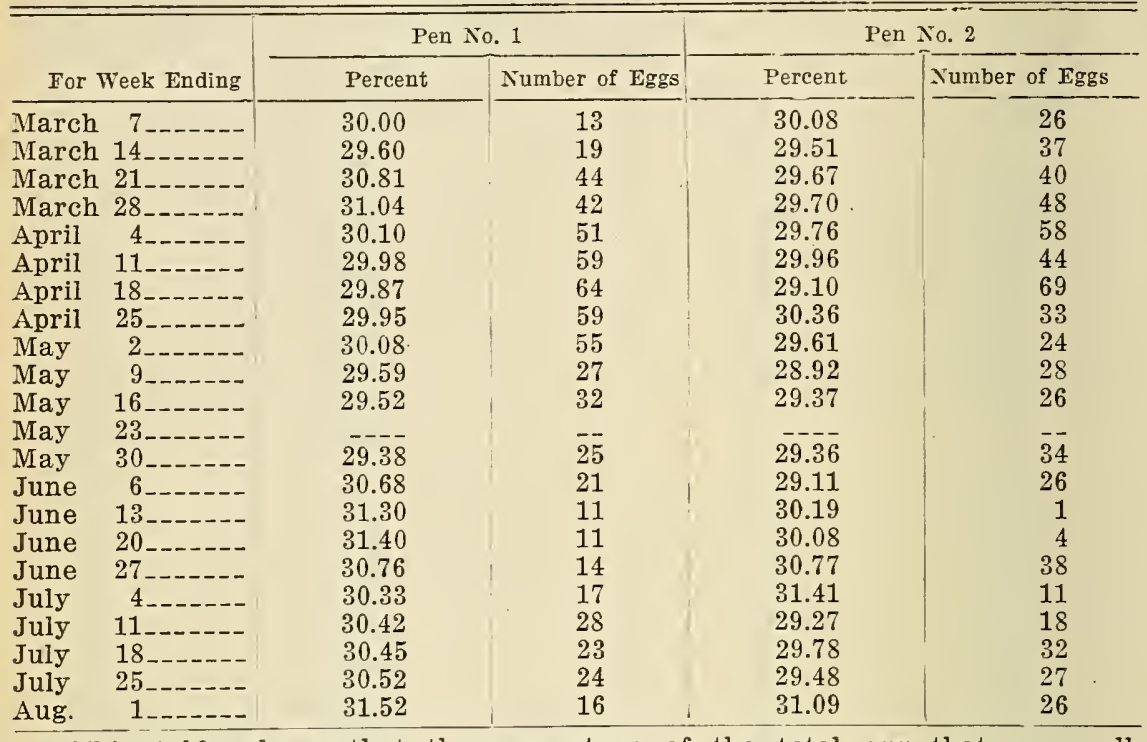

This table shows that the percentage of the total egg that was yolk averaged somewhat smaller in the case of the wheat fed fowls.

TABLE IV.--Eggs of Pen 1 for 1915 Classified According to Weight.

\begin{tabular}{|c|c|c|c|c|}
\hline Grouping & $\begin{array}{l}\text { Number of Eggs } \\
\text { and Yolks }\end{array}$ & $\begin{array}{l}\text { Average Weight } \\
\text { of Eggs in Grams }\end{array}$ & $\begin{array}{l}\text { Average Weight } \\
\text { of Yolks in Gr'ms }\end{array}$ & $\begin{array}{l}\text { Percent } \\
\text { Yolk }\end{array}$ \\
\hline & $\begin{array}{l}6 \\
5\end{array}$ & $\begin{array}{l}43.46 \\
44.56\end{array}$ & $\begin{array}{l}12.989 \\
13.418\end{array}$ & $\begin{array}{l}29.89 \\
30.11\end{array}$ \\
\hline & 13 & 45.56 & 13.994 & 30.72 \\
\hline & 25 & 46.67 & 14.149 & 30.32 \\
\hline & 29 & 47.48 & 14.838 & 31.25 \\
\hline & 53 & 48.49 & 14.897 & 30.73 \\
\hline \multirow{6}{*}{$\begin{array}{l}\text { Average Between } 45.00 \\
\quad \text { and } 49.99 \text { Grams.-- }\end{array}$} & 75 & 49.48 & 15.179 & 30.68 \\
\hline & 195 & 48.29 & 14.841 & 30.73 \\
\hline & 64 & 50.49 & 15.345 & 30.39 \\
\hline & 58 & 51.49 & 15.778 & 30.64 \\
\hline & 55 & 52.50 & 15.913 & 30.31 \\
\hline & 47 & 53.46 & 16.024 & 29.97 \\
\hline \multirow{7}{*}{$\begin{array}{l}\text { Average Between } 50.00 \\
\text { and } 54.99 \text { Grams.-- }\end{array}$} & 48 & 54.44 & 16.292 & 29.93 \\
\hline & 272 & 52.32 & 15.837 & 30.27 \\
\hline & 46 & 55.43 & 16.362 & 29.52 \\
\hline & 43 & 56.39 & 17.023 & 30.19 \\
\hline & 36 & 57.48 & 16.995 & 29.57 \\
\hline & 24 & 58.52 & 17.715 & 30.27 \\
\hline & 17 & 59.52 & 17.657 & 29.67 \\
\hline \multirow{4}{*}{$\begin{array}{l}\text { Average Between } 55.00 \\
\text { and } 60.99 \text { Grams.-- }\end{array}$} & 11 & 60.48 & 17.764 & 29.37 \\
\hline & 177 & 57.21 & 17.046 & 29.80 \\
\hline & 3 & 61.17 & 18.593 & 30.40 \\
\hline & 2 & 62.52 & 18.892 & 30.22 \\
\hline \multicolumn{5}{|l|}{ Average Between 45.00} \\
\hline $\begin{aligned} \text { and } & 60.99 \text { Grams } \\
\text { Total } & \text { Average }\end{aligned}$ & 644 & 52.45 & $\begin{array}{l}15.868 \\
15.844\end{array}$ & $\begin{array}{l}30.25 \\
30.25\end{array}$ \\
\hline Total Average & 660 & 02.38 & 10.844 & 00.20 \\
\hline
\end{tabular}


TABLE V.-Eggs of Pen 2 for 1915 Classified According to Weight.

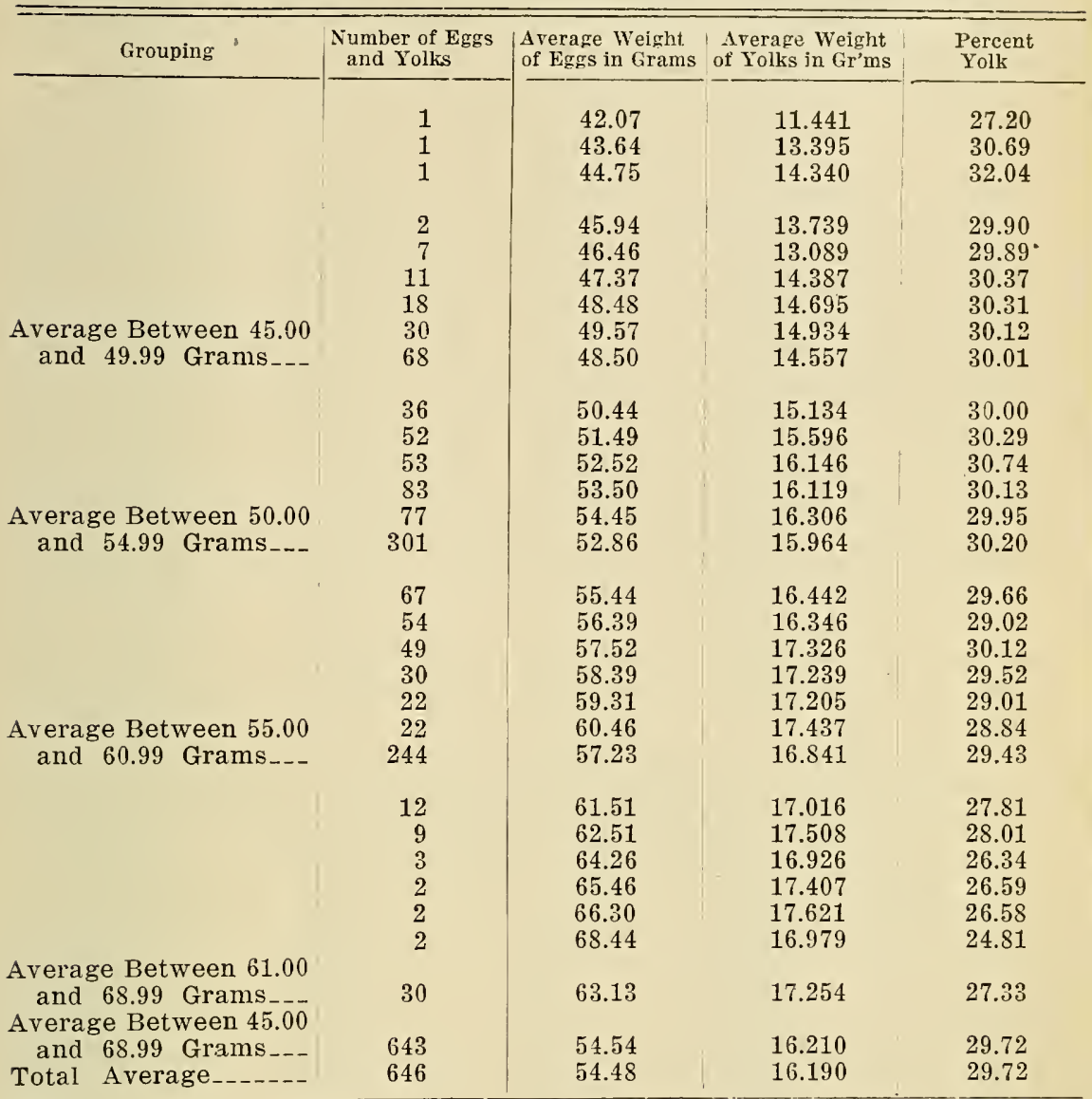

From the two preceding tables the following. conclusions may be drawn:

1. The heavier the egg, the smaller the percent of the total egg that is yolk.

2. The lighter the egg, the greater the percent of the total egg that is yolk.

3. The heavier the egg, the heavier the yolk.

4. The hens in the corn fed pen laid lighter eggs than did the hens in the wheat fed pen. 
5. The yolks of the eggs laid by the wheat fed fowls were heavier than those laid by the corn fed fowls, but the percentage of the total egg that was yolk was smaller.

\section{Results for 1916.}

Table VI which follows gives the number and average weight in grams of the eggs which were examined during 1916, arranged and averaged according to weeks. Table VII shows the number and average weight of the yolks of the eggs which were examined in 1916 , arranged and averaged according to weeks. Table VIII was derived from Tables VI and VII and shows the percentage of yolk in the eggs examined. Table IX compares the averages for the years 1915 and 1916. Table $\mathrm{X}$ classifies the eggs of Pen 1 according to weight and gives the percentage of yolk. Table XI classifies the eggs of Pen 2 according to weight and gives the percentage of yolk.

TABLE VI.-Number and Average Weight of Eggs Obtained From Pens 1 and 2 During 1916.

\begin{tabular}{|c|c|c|c|c|c|}
\hline \multirow{2}{*}{\multicolumn{2}{|c|}{ For Week Ending }} & \multicolumn{2}{|c|}{ Pen No. 1} & \multicolumn{2}{|c|}{ Pen No. 2} \\
\hline & & $\begin{array}{l}\text { Average Weight } \\
\text { in Grams }\end{array}$ & No. of Eggs & $\begin{array}{c}\text { Average Weight } \\
\text { iii Grams }\end{array}$ & No. of Eggs \\
\hline Feb. & $27 \ldots$ & 56.18 & 15 & 58.05 & 4 \\
\hline March & h $5 \ldots$ & 57.36 & 25 & 60.44 & 5 \\
\hline March & h $12 \ldots$ & 56.95 & 32 & 59.91 & 18 \\
\hline March & h $19 \ldots$ & 56.53 & 31 & 59.35 & 23 \\
\hline March & h $26 \ldots---$ & 55.31 & 17 & 58.94 & 19 \\
\hline April & 2 & 56.68 & 37 & 58.01 & 26 \\
\hline April & $9 \ldots$ & 58.91 & 33 & 58.57 & 24 \\
\hline April & $16 \ldots$ & 58.99 & 23 & 57.96 & 18 \\
\hline April & $23 \ldots \ldots$ & 58.92 & 12 & 55.72 & 7 \\
\hline April & $30 \ldots \ldots-\ldots$ & 57.76 & 29 & 56.36 & 24 \\
\hline May & $7-\ldots$ & 57.63 & 25 & 56.75 & 21 \\
\hline May & $14 \ldots$ & 55.23 & 12 & 57.15 & 12 \\
\hline May & $21 \ldots \ldots$ & 55.29 & 23 & 54.88 & 11 \\
\hline May & $28 \ldots$ & 54.54 & 19 & 54.12 & 17 \\
\hline June & 4 & 53.39 & 10 & 52.69 & 6 \\
\hline June & $11-------$ & 55.69 & 16 & 56.21 & 20 \\
\hline June & $18 \ldots \ldots$ & 55.68 & 17 & 55.07 & 20 \\
\hline June & $25 \ldots \ldots$ & 54.08 & 15 & 56.17 & 24 \\
\hline July & 2 & 54.21 & 8 & 54.56 & 19 \\
\hline July & $9 \ldots$ & 58.11 & 6 & 54.46 & 5 \\
\hline July & $16 \ldots$ & 56.52 & 16 & 54.77 & 8 \\
\hline July & $23 \ldots \ldots$ & 55.56 & 20 & 53.69 & 12 \\
\hline
\end{tabular}


TABLE VII.-Number and Average Weight of Yolks Obtained From Pens 1 and 2 During 1916.

\begin{tabular}{|c|c|c|c|c|c|}
\hline & & Pen $N$ & & Pen & \\
\hline For $\pi$ & reek Ending & $\begin{array}{l}\text { Average Weight } \\
\text { in Grams }\end{array}$ & No. of Yolks & $\begin{array}{l}\text { Average Weight } \\
\text { in Granis }\end{array}$ & No. of lolks \\
\hline $\begin{array}{l}\text { Feb. } \\
\text { March }\end{array}$ & $27-\cdots--$ & $\begin{array}{l}18.013 \\
17.882\end{array}$ & 15 & 18.004 & 4 \\
\hline March & 12 & 18.063 & $\begin{array}{l}20 \\
32\end{array}$ & $\begin{array}{l}18.098 \\
18.384\end{array}$ & $\begin{array}{r}5 \\
18\end{array}$ \\
\hline March & 19 & 17.703 & 31 & 18.374 & 23 \\
\hline March & $26 \ldots$ & 17.668 & 17 & 18.362 & 19 \\
\hline April & 2 & 17.636 & 37 & 17.987 & 26 \\
\hline April & 9 & 18.502 & 33 & 17.933 & 24 \\
\hline April & $16 \ldots \ldots$ & 18.350 & 23 & 18.149 & 18 \\
\hline April & $23 \ldots \ldots \ldots$ & 18.820 & 12 & 17.666 & 7 \\
\hline April & $30 \ldots \ldots$ & 17.991 & 29 & 17.492 & 24 \\
\hline May & 7 & 17.659 & 25 & 17.774 & 21 \\
\hline May & 14 & 17.364 & 12 & 17.996 & 12 \\
\hline May & $21 \ldots \ldots$ & 17.405 & 23 & 17.481 & 11 \\
\hline May & $28 \ldots \ldots$ & 17.067 & 19 & 16.733 & 17 \\
\hline June & 4 & 16.397 & 10 & 16.183 & 6 \\
\hline June & $11 \ldots \ldots$ & 16.359 & 16 & 17.766 & 20 \\
\hline June & $18 \ldots$ & 16.770 & 17 & 17.815 & 20 \\
\hline June & $25 \ldots \ldots$ & 15.968 & 15 & 18.081 & 24 \\
\hline July & 2 & 17.079 & 8 & 17.523 & 19 \\
\hline July & 9 & 17.151 & 6 & 17.754 & 5 \\
\hline July & $16 \ldots$ & 17.788 & 16 & 18.068 & 8 \\
\hline July & $23 \ldots \ldots$ & 16.730 & 20 & 17.171 & 12 \\
\hline
\end{tabular}

TABLE VIII.-Number and Average Percentage of Yolks in Eggs Obtained From Pens 1 and 2 During 1916.

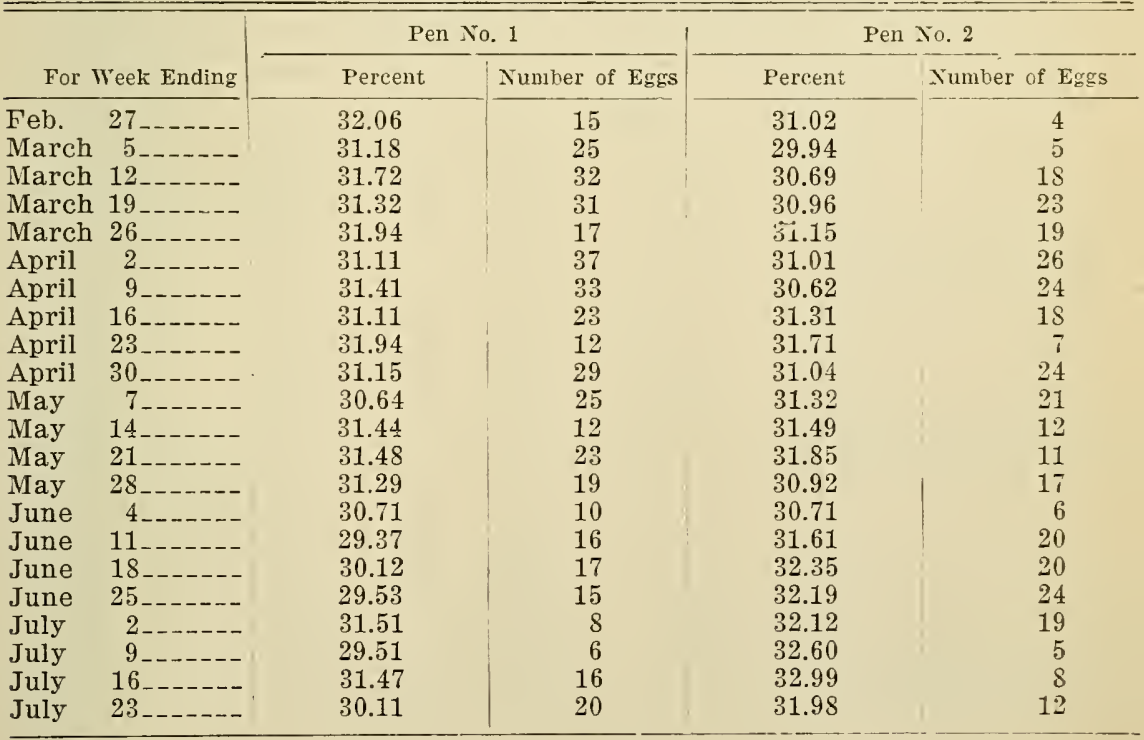


TABLE IX.-Comparison of the Averages for 1915 and 1916.

\begin{tabular}{c|c|c|c|c|c|c|c|c}
\hline & \multicolumn{2}{c}{ No. of Eggs } & \multicolumn{2}{c}{$\begin{array}{c}\text { Average Weight in } \\
\text { Grams }\end{array}$} & \multicolumn{2}{c}{$\begin{array}{c}\text { Average Wt. of Yolks } \\
\text { in Grams }\end{array}$} & \multicolumn{2}{c}{$\begin{array}{c}\text { Average Percent } \\
\text { of Yolks }\end{array}$} \\
\cline { 2 - 10 } Pens & 1915 & 1916 & 1915 & 1916 & 1915 & 1916 & 1915 & 1916. \\
\hline Pen 1-- & 660 & 441 & 52.38 & 56.60 & 15.844 & 17.598 & 30.25 & 31.09 \\
Pen 2-- & 646 & 343 & 54.48 & 56.79 & 16.190 & 17.825 & 29.72 & 31.39 \\
\hline
\end{tabular}

During both years the average weight of the eggs and yolks was somewhat greater from the wheat fed fowls, the difference being more pronounced in 1915 when the minimum amount of beef scrap was fed. Also, the average weight of the eggs and yolks in 1916 was greater than in 1915. Undoubtedly this difference was partially due to the age of the fowls, and possibly to a certain extent to the increased amount of beef scrap. The percentage of the total egg that was yolk was also greater during the second year but, contrary to the results obtained in 1915, the total percentage of the eggs that was yolk was greater in 1916 in the eggs from the wheat fed fowls.

TABLE X.-Eggs of Pen 1 for 1916 Classified According to Weight.

\begin{tabular}{|c|c|c|c|c|}
\hline Grouping & $\begin{array}{l}\text { Number of Eggs } \\
\text { and Yolks }\end{array}$ & $\begin{array}{l}\text { Average Weight } \\
\text { of Eggs in Grams }\end{array}$ & $\begin{array}{l}\text { A rerage Weight } \\
\text { of Yolks in Gr'ms }\end{array}$ & $\begin{array}{l}\text { Percent } \\
\text { Yolk }\end{array}$ \\
\hline \multirow{7}{*}{$\begin{array}{l}\text { Arerage Between } 45.00 \\
\text { and } 49.99 \text { Grams_-- }\end{array}$} & 3 & 44.60 & 14.891 & 33.39 \\
\hline & 2 & 45.65 & 13.529 & 29.64 \\
\hline & 2 & 46.24 & 15.607 & 33.75 \\
\hline & 4 & 47.68 & 15.781 & 33.10 \\
\hline & 6 & 48.57 & 15.389 & 31.68 \\
\hline & 10 & 49.60 & 15.991 & 32.24 \\
\hline & 24 & 48.41 & 15.568 & 32.16 \\
\hline \multirow{6}{*}{$\begin{array}{l}\text { Average Between } 50.00 \\
\text { and } 54.99 \text { Grams }\end{array}$} & 17 & 50.62 & 16.136 & 31.87 \\
\hline & 19 & 51.55 & 15.952 & 30.94 \\
\hline & 30 & 52.49 & 16.281 & 31.02 \\
\hline & 40 & 53.52 & 16.560 & 30.94 \\
\hline & 42 & 54.41 & 16.795 & 30.87 \\
\hline & 148 & 52.98 & 16.443 & 31.04 \\
\hline \multirow{7}{*}{$\begin{array}{l}\text { Arerage Between } 55.00 \\
\text { and } 60.99 \text { Grams }\end{array}$} & 48 & 55.56 & 17.295 & 31.13 \\
\hline & 36 & 56.45 & 18.063 & 32.00 \\
\hline & 27 & 57.44 & 18.284 & 31.83 \\
\hline & 26 & 58.57 & 18.817 & 32.13 \\
\hline & 36 & 59.53 & 18.636 & 31.30 \\
\hline & 13 & 60.59 & 18.720 & 30.90 \\
\hline & 186 & 57.55 & 18.159 & 31.55 \\
\hline
\end{tabular}


September, 1917] CHARACTERISTICS OF HEN EGGS

TABLE X (Cont'd).-Eggs of Pen 1 for 1916 Classified According to Weight.

\begin{tabular}{c|c|c|c|c}
\hline \hline Grouping & $\begin{array}{c}\text { Number of Eggs } \\
\text { and Yolks }\end{array}$ & $\begin{array}{c}\text { Average Weight } \\
\text { of Eggs in Grams }\end{array}$ & $\begin{array}{c}\text { Average Weight } \\
\text { of Yolks in Gr'ms }\end{array}$ & $\begin{array}{c}\text { Percent } \\
\text { Yolk }\end{array}$ \\
\cline { 3 - 4 } & 15 & 61.53 & 19.111 & 30.99 \\
& 17 & 62.42 & 18.786 & 30.10 \\
& 13 & 63.56 & 19.563 & 30.78 \\
& 9 & 64.37 & 19.281 & 29.95 \\
& 13 & 65.42 & 18.647 & 28.50 \\
Average Between 61.00 & 3 & 66.51 & 19.133 & 28.77 \\
and 68.99 Grams_-- & 2 & 67.53 & 20.714 & 30.67 \\
& 79 & 68.35 & 19.312 & 28.25 \\
Average Between 45.00 & 1 & 63.97 & 19.118 & 29.89 \\
and 68.99 Grams_-- & 437 & 69.61 & & \\
Total Average_------ & 441 & 56.66 & 20.931 & 30.07 \\
\hline
\end{tabular}

TABLE XI.-Eggs of Pen 2 for 1916 Classified According to Weight.

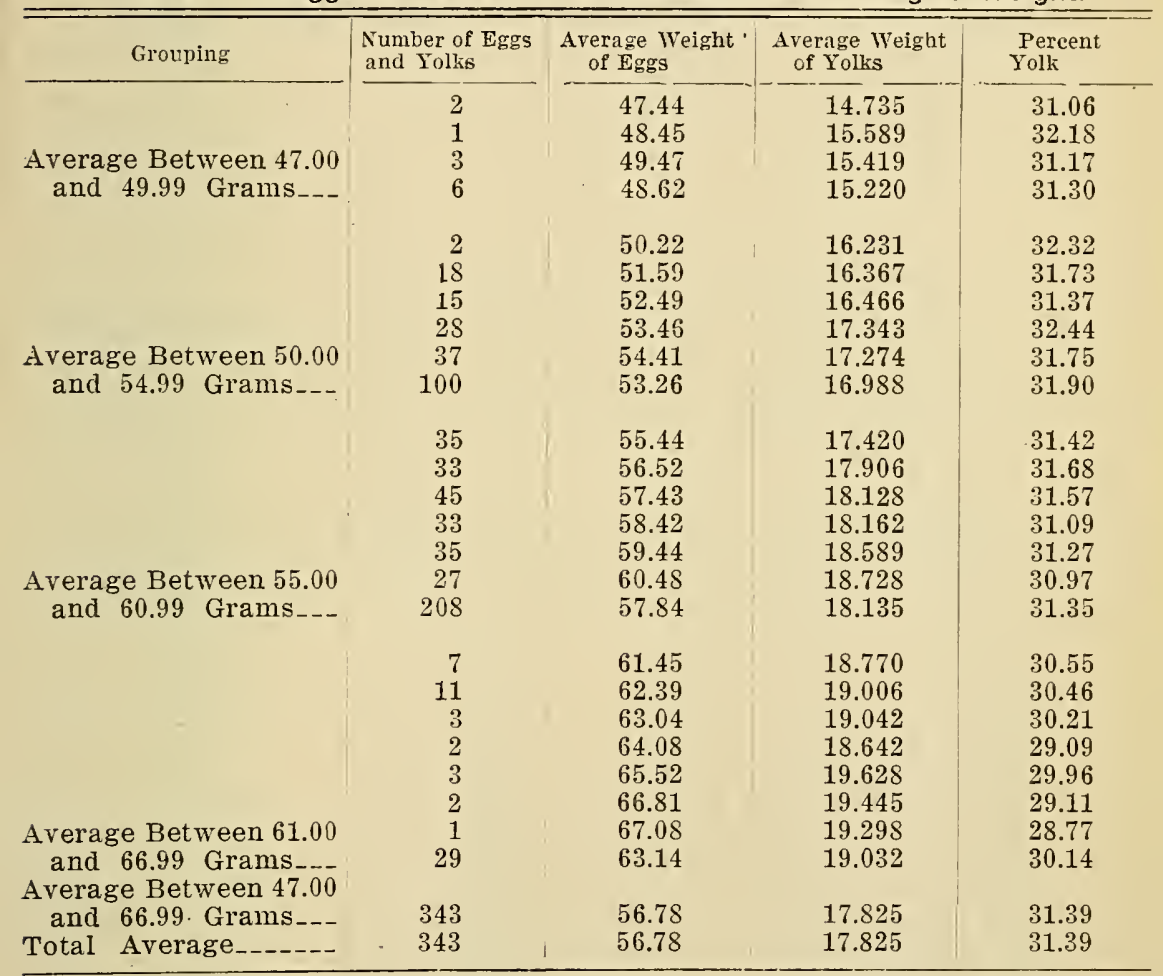

From these tables it may be observed that similar to the results obtained in 1915, the heavier the egg the heavier the yolk, but the heavier the egg, the smaller is the total percentage of the egg that is yolk. 


\section{EGG CYCLES.}

When a hen lays on two or more days in succession the eggs laid consecutively constitute a cycle; consequently, cycles may consist of two or more eggs. It seemed wise to examine somewhat carefully the influence of the position of the egg in the cycle on its weight and on the weight of the yolk. In other words, suppose that a hen lays an egg on April 1, another on April 2, and still another on April 3 with no production on April 4 and then begins another cycle. How do the eggs which were laid consecutively on the different days compare with reference to their weight and the weight of their yolks?

\section{INFLUENCE OF THE POSITION OF THE EGG IN THE CYCLE ON THE WEIGHT OF EGGS.}

Two-Egg Cycles.-The eggs laid by each hen during the two years have been arranged according to cycles, and in the following table the average weights of the eggs laid on the first day and on the second day of the two-egg cycles have been brought together. It was not possible to weigh all of the yolks on account of the fact that some of the eggs were incubated and some of the yolks were broken in the separation; hence the results are discussed first with reference to the influence on the weight of the eggs, then consideration is given to those eggs in the various cycles the yolks of which were weighed. The following tables give the data for the two pens for 1915 and 1916 :

TABLE XII.-Data on Pen 1 for 1915 Showing Number of Egg Cycles and Average Weights of Eggs for First and Second Days of Two-Egg Cycles.

\begin{tabular}{c|c|c|c}
\hline \hline Hen No. & No. Egg Cycles & Ave. Weight First Day & Ave. Weight Second Day \\
\hline 581 & 19 & 52.18 & 52.24 \\
582 & 11 & 50.51 & 48.64 \\
583 & 8 & 58.65 & 54.64 \\
584 & 8 & 56.17 & 54.59 \\
586 & 10 & 53.94 & 53.24 \\
587 & 16 & 49.27 & 46.99 \\
588 & 16 & 49.69 & 48.53 \\
589 & 23 & 50.95 & 48.69 \\
595 & 17 & 58.82 & 56.25 \\
585 & 6 & 48.63 & 47.22 \\
590 & 11 & 55.41 & 54.26 \\
591 & 3 & 54.45 & 55.02 \\
592 & 11 & 49.27 & 47.81 \\
593 & 11 & 51.61 & 48.36 \\
596 & 9 & 54.19 & 49.71 \\
597 & 5 & 54.61 & 52.67 \\
Average & 184 & 52.69 & 50.83 \\
\hline
\end{tabular}


TABLE XIII.-Data on Pen 2 for 1915 Showing Number of Egg Cycles and Average Weights of Eggs for First and Second Days of Two-Egg Cycles.

\begin{tabular}{crcc}
\hline \hline Hen No. & No. Egg Cycles & Ave. Weight First Day & \multirow{2}{*}{ Ave. Weight Second Day } \\
654 & 20 & 54.31 & 52.82 \\
634 & 5 & 51.35 & 51.09 \\
625 & 16 & 57.00 & 54.74 \\
629 & 15 & 50.87 & 49.35 \\
680 & 12 & 56.87 & 53.59 \\
694 & 12 & 53.87 & 53.41 \\
678 & 21 & 56.53 & 53.94 \\
671 & 14 & 56.05 & 53.64 \\
645 & 12 & 61.08 & 58.38 \\
202 & 6 & 56.30 & 53.37 \\
615 & 9 & 61.54 & 58.36 \\
623 & 3 & 54.37 & 53.02 \\
620 & 8 & 53.57 & 54.28 \\
669 & 15 & 56.78 & 56.37 \\
631 & 10 & 56.67 & 53.93 \\
660 & 9 & 54.41 & 55.59 \\
617 & 4 & 51.85 & 53.50 \\
Average & 191 & 55.76 & 54.10 \\
& & &
\end{tabular}

TABLE XIV.-Data on Pen 1 for 1916 Showing Number of Egg Cycles and Average Weights of Eggs for First and Second Days of Two-Egg Cycles.

\begin{tabular}{c|c|c|c}
\hline \hline Hen. No. & No. Egg Cycles & Ave. Weight First Day & Ave. Weight Second Day \\
\cline { 2 - 3 } & 11 & 58.00 & 56.23 \\
581 & 11 & 64.18 & 59.56 \\
583 & 9 & 55.98 & 55.18 \\
584 & 9 & 52.10 & 50.12 \\
585 & 13 & 56.94 & 53.39 \\
587 & 7 & 53.25 & 51.30 \\
588 & 12 & 52.67 & 49.44 \\
589 & 13 & 61.98 & 57.69 \\
590 & 10 & 65.85 & 62.43 \\
591 & 17 & 53.53 & 50.85 \\
592 & 14 & 51.48 & 48.58 \\
593 & 14 & 61.25 & 59.50 \\
595 & 7 & 55.85 & 52.00 \\
596 & 7 & 57.52 & 55.24 \\
597 & 154 & 57.19 & 54.35 \\
Average & & & \\
\hline
\end{tabular}


TABLE XV.-Data on Pen 2 for 1916 Showing Number of Egg Cycles and Average Weights of Eggs for First and Second Days of Two-Egg Cycles.

\begin{tabular}{c|r|c|c}
\hline Hen. No. & No. Egg Cycles & Ave. Weight First Day & Ave. Weight Second Day \\
\cline { 1 - 2 } 631 & 19 & 56.41 & 51.03 \\
660 & 17 & 54.88 & 52.12 \\
620 & 20 & 57.38 & 54.58 \\
625 & 6 & 59.58 & 58.03 \\
680 & 9 & 58.04 & 54.58 \\
671 & 4 & 58.56 & 56.18 \\
678 & 22 & 57.17 & 54.85 \\
694 & 11 & 58.59 & 58.04 \\
629 & 3 & 56.94 & 54.65 \\
615 & 15 & 63.40 & 61.18 \\
669 & 11 & 59.99 & 60.06 \\
Average & 137 & 58.03 & 55.46 \\
\hline
\end{tabular}

The tables show that in practically all instances the first eggs laid were the heavier, the average difference varying between 1.6 and 2.8 grams, the smaller variation being in the first year of the test.

Three-Egg Cycles.-The following tables give the data on the weights of the eggs when three eggs were laid in succession:

TABLE XVI.-Data on Pen 1 for 1915 Showing Number of Egg Cycles and Average Weights of Eggs for First, Second, and Third Days of Three-Egg Cycles.

\begin{tabular}{c|c|cc|c}
\hline \hline Hen No. & No. Egg Cycles & $\begin{array}{c}\text { Average Weight } \\
\text { First Day }\end{array}$ & $\begin{array}{c}\text { Average weight } \\
\text { Second Day }\end{array}$ & $\begin{array}{c}\text { Average Weight } \\
\text { Third Day }\end{array}$ \\
\hline 581 & 2 & 54.51 & 53.62 & 53.81 \\
582 & 3 & 60.41 & 56.01 & 55.37 \\
584 & 7 & 56.46 & 56.75 & 56.39 \\
586 & 2 & 57.27 & 55.36 & 53.14 \\
587 & 2 & 49.61 & 49.44 & 49.05 \\
588 & 8 & 50.57 & 49.54 & 48.75 \\
589 & 7 & 49.75 & 49.03 & 47.68 \\
595 & 2 & 57.78 & 56.13 & 57.36 \\
585 & 4 & 50.44 & 50.21 & 47.88 \\
590 & 1 & 56.53 & 55.63 & 58.10 \\
592 & 4 & 48.56 & 49.49 & 48.91 \\
593 & 1 & 51.28 & 47.99 & 56.07 \\
596 & 2 & 53.62 & 51.31 & 51.47 \\
597 & 1 & 56.78 & 57.13 & 51.24 \\
Average & 46 & 52.94 & 52.09 & \\
\hline
\end{tabular}


TABLE XVII.-Data on Pen 2 for 1915 Showing Number of Egg Cycles and Average Weights of Eggs for First, Second, and Third Days of Three-Egg Cycles.

\begin{tabular}{|c|c|c|c|c|}
\hline Hen No. & No. Egg Cycles & $\begin{array}{l}\text { Average Weight } \\
\text { Finst Day }\end{array}$ & $\begin{array}{c}\text { Average Weight } \\
\text { Second Day }\end{array}$ & $\begin{array}{l}\text { Average Weight } \\
\text { Third Day }\end{array}$ \\
\hline 654 & 7 & 53.07 & 52.21 & 51.77 \\
\hline 634 & 9 & 51.72 & 51.97 & 50.25 \\
\hline 625 & 8 & 56.74 & 56.36 & 56.17 \\
\hline 629 & 2 & 53.13 & 51.28 & 51.35 \\
\hline 680 & 2 & 54.30 & 55.18 & 53.07 \\
\hline 694 & 8 & 54.09 & 55.08 & 55.12 \\
\hline 678 & 4 & 54.33 & 54.25 & 55.43 \\
\hline 671 & 3 & 56.78 & 54.98 & 54.00 \\
\hline 645 & 2 & 61.22 & 61.45 & 60.36 \\
\hline 202 & 1 & 56.58 & 51.88 & 49.89 \\
\hline 620 & 1 & 53.81 & 55.61 & 55.29 \\
\hline 669 & 4 & 56.72 & 56.93 & 55.88 \\
\hline 631 & 2 & 59.30 & 55.77 & 54.16 \\
\hline Average & $5 \overline{3}$ & 54.83 & 54.51 & 53.87 \\
\hline
\end{tabular}

TABLE XVIII.-Data on Pen 1 for 1916 Showing Number of Egg Cycles and Average Weights of Eggs for First, Second, and Third Days of Three-Egg Cycles.

\begin{tabular}{c|c|c|c|c}
\hline \hline Hen No. & No. Egg Cycles & $\begin{array}{c}\text { Average Weight } \\
\text { First Day }\end{array}$ & $\begin{array}{c}\text { Average Weight } \\
\text { Second Day }\end{array}$ & $\begin{array}{c}\text { Average Weight } \\
\text { Third Day }\end{array}$ \\
\cline { 1 - 2 } 5 & 14 & 59.48 & 58.01 & 56.89 \\
583 & 3 & 63.87 & 59.16 & 60.29 \\
584 & 3 & 60.32 & 58.59 & 57.11 \\
585 & 3 & 56.60 & 54.28 & 52.08 \\
587 & 5 & 58.11 & 54.13 & 53.18 \\
588 & 2 & 46.30 & 45.03 & 44.49 \\
589 & 9 & 53.25 & 51.98 & 50.02 \\
590 & 9 & 63.88 & 62.20 & 61.88 \\
591 & 1 & 68.77 & 68.07 & 64.27 \\
592 & 2 & 54.54 & 52.78 & 53.35 \\
593 & 6 & 53.93 & 52.47 & 51.32 \\
596 & 6 & 59.31 & 57.21 & 55.83 \\
Average & 63 & 58.25 & 56.32 & 55.25 \\
\hline
\end{tabular}

TABLE XIX.-Data on Pen 2 for 1916 Showing Number of Egg Cycles and Average Weights of Eggs for First, Second, and Third Days of Three-Egg Cycles.

\begin{tabular}{|c|c|c|c|c|}
\hline Hen No. & No. Egg Cycles & $\begin{array}{l}\text { Arerage Weight } \\
\text { Finst Day }\end{array}$ & $\begin{array}{l}\text { Average Weight } \\
\text { Second Day }\end{array}$ & $\begin{array}{c}\text { Average Weight } \\
\text { Third Day }\end{array}$ \\
\hline 631 & 6 & 57.21 & 51.82 & 50.46 \\
\hline 660 & 6 & 53.32 & 53.32 & 48.23 \\
\hline 620 & 6 & 55.57 & 55.02 & 54.04 \\
\hline 625 & 16 & 58.88 & 56.85 & 55.33 \\
\hline 680 & 7 & 57.40 & 55.46 & 52.69 \\
\hline 671 & 4 & 54.82 & 54.59 & 52.90 \\
\hline 678 & 6 & 57.29 & 55.93 & 54.07 \\
\hline 694 & 2 & 54.36 & 54.16 & 55.26 \\
\hline 629 & 1 & 55.50 & 52.00 & 52.95 \\
\hline 615 & 11 & 65.25 & 63.62 & 61.45 \\
\hline 669 & 13 & 60.83 & 59.12 & 57.94 \\
\hline Average & 78 & 58.67 & 56.94 & 55.12 \\
\hline
\end{tabular}

These tables are in agreement with the preceding ones, as the first eggs in the cycles are the heaviest, and the last eggs the lightest, the eggs laid on the second day being intermediate between the two extremes. 
Four-Egg Cycles.-The following table gives the data for the four-egg cycles:

TABLE XX.-Number of Egg Cycles and Average Weight of Eggs in Four-Egg Cycles.

\begin{tabular}{c|c|c|c|c|c|c}
\hline Iear & Pen & No. Cycles & First Day & Second Day & Third Day & Fourth Day \\
\hline 1915 & 1 & 10 & 53.68 & 53.07 & 52.13 & 52.44 \\
1915 & 2 & 10 & 54.10 & 53.08 & 53.51 & 53.55 \\
1916 & 16 & 55.78 & 54.30 & 52.77 & 52.36 \\
$1916-\cdots---$ & 2 & 27 & 56.64 & 56.45 & 54.90 & 53.88 \\
Arerage -- & & 63 & 55.53 & 54.83 & 53.70 & 53.21 \\
\hline
\end{tabular}

The table shows that the average weight of the eggs diminishes as the position of the egg in the cycle advances.

Five-Egg Cycles.-The following table gives the data for the fiveegg cycles:

TABLE XXI.-Number of Egg Cycles and Average Weight of Eggs in the FiveEgg Cycles.

\begin{tabular}{|c|c|c|c|c|c|c|c|}
\hline & & $\begin{array}{r}\text { No. } \\
\text { Cycles }\end{array}$ & First Day & Second Day & Third Day & Fourth Day & Fifth Day \\
\hline$\ldots$ & 2 & 3 & 54.05 & 52.61 & 53.68 & 53.40 & 51.67 \\
\hline 1916 & 1 & 4 & 54.94 & 53.22 & 52.70 & 52.51 & 51.08 \\
\hline 1916 & 2 & 10 & 58.41 & 58.28 & 57.78 & 55.96 & 54.65 \\
\hline Average & & 17 & 56.83 & 56.09 & 55.87 & 54.70 & 53.28 \\
\hline
\end{tabular}

This table is in agreement with the preceding ones as the weight of the egg decreases as the position of the egg advances in the cycle.

Other cycles were obtained containing as many as nine eggs, but the available data are so few that reliable averages cannot be obtained.

\section{INFLUENCE OF THE POSITION OF THE EGG IN THE CYCLE ON THE YOLK WEIGHT.}

From the standpoint of the vigor of the embryo, a variation in the weight of the yolks of eggs is probably at least of as great importance as the weight of the egg. In the following tables are arranged the cycles in which the weight of the yolks were determined for all the eggs in each cycle.

In the discussion of these data, it may be observed that the number of cycles in 1916 is considerably smaller than in 1915. This is partly due to the fact that in 1916 it seemed to be more difficult to separate the yolks from the whites, as the vitelline membrane seemed to be weaker. 
This apparent weakness may have been due to the narrower ration fed in 1916, as it has been observed (Cornell Experiment Station Bulletin 25) that a nitrogenous ration seems to weaken the membrane surrounding the yolks.

The following tables give the average weight of eggs and yolks laid by the various hens in the two-egg cycles:

TABLE XXII.-Average Weight of Eggs and Yolks in Two-Egg Cycles From Pen 1 in 1915.

\begin{tabular}{|c|c|c|c|c|c|}
\hline Hen No. & Eggs & Day & $\begin{array}{l}\text { Average Weight } \\
\text { of Eggs }\end{array}$ & $\begin{array}{l}\text { Average Weight } \\
\text { of Yolks }\end{array}$ & Percent Yolk \\
\hline 581 & 17 & 1 & 52.53 & 17.041 & 32.44 \\
\hline 581 & 17 & 2 & 52.33 & 16.677 & 31.87 \\
\hline 582 & 9 & 1 & 50.44 & 15.737 & 31.20 \\
\hline 582 & 9 & 2 & 48.51 & 15.427 & 31.80 \\
\hline 583 & 5 & 1 & 58.36 & 16.571 & 28.39 \\
\hline 583 & 5 & 2 & 55.30 & 16.887 & 30.54 \\
\hline 584 & 6 & 1 & 56.49 & 17.155 & 30.37 \\
\hline 584 & 6 & 2 & 54.39 & 16.839 & 30.96 \\
\hline 586 & 8 & 1. & 54.96 & 15.666 & 28.50 \\
\hline 586 & 8 & 2 & 53.78 & 15.437 & 28.70 \\
\hline 587 & 12 & 1 & 48.90 & 14.197 & 29.03 \\
\hline 587 & 12 & 2 & 47.11 & 14.029 & 29.78 \\
\hline 588 & 13 & 1 & 49.98 & 15.806 & 31.63 \\
\hline 588 & 13 & 2 & 48.55 & 15.460 & 31.84 \\
\hline 589 & 15 & 1 & 51.26 & 15.297 & 29.84 \\
\hline $589^{\circ}$ & 15 & 2 & 49.13 & 15.076 & 30.69 \\
\hline 595 & 14 & 1 & 58.40 & 17.964 & 30.76 \\
\hline 595 & 14 & 2 & 56.60 & 17.621 & 31.13 \\
\hline 585 & 3 & 1 & 50.45 & 15.198 & 30.12 \\
\hline 585 & 3 & 2 & 48.25 & 14.284 & 29.61 \\
\hline 590 & 6 & 1 & 54.82 & 14.857 & 27.10 \\
\hline 590 & 6 & 2 & 54.35 & 15.243 & 28.05 \\
\hline 591 & 1 & 1 & 55.86 & 13.699 & 24.52 \\
\hline 591 & 1 & 2 & 53.65 & 14.186 & 26.44 \\
\hline 592 & 2 & 1 & 51.03 & 16.475 & 32.29 \\
\hline 592 & 2 & 2 & 48.80 & 16.138 & 33.07 \\
\hline 593 & 2 & 1 & 50.93 & 15.342 & 30.12 \\
\hline 593 & 2 & 2 & 48.05 & 15.092 & 31.41 \\
\hline 596 & 3 & 1 & 54.05 & 14.391 & 26.62 \\
\hline 596 & 3 & 2 & 50.05 & 14.022 & 28.02 \\
\hline 597 & 2 & $\overline{1}$ & 54.42 & 17.198 & 31.60 \\
\hline 597 & 2 & 2 & 52.37 & 16.447 & 31.41 \\
\hline \multirow[t]{2}{*}{ Total } & 118 & 1 & 52.98 & 16.007 & 30.21 \\
\hline & 118 & 2 & 51.34 & 15.757 & 30.69 \\
\hline
\end{tabular}


TABLE XXIII.-Average Weight of Eggs and Yolks in Two-Egg Cycles From Pen 2 in 1915.

\begin{tabular}{|c|c|c|c|c|c|}
\hline Hen No. & Eggs & Day & $\begin{array}{l}\text { Average Weight } \\
\text { of Eggs }\end{array}$ & $\begin{array}{l}\text { Average Weight } \\
\text { of Yolks }\end{array}$ & Percent Yolk \\
\hline $\begin{array}{l}654 \\
654 \\
634 \\
634 \\
625 \\
625 \\
629 \\
629 \\
680 \\
680 \\
694 \\
694 \\
678 \\
678 \\
671 \\
671 \\
645 \\
645 \\
202 \\
202 \\
615 \\
615 \\
620 \\
620 \\
669 \\
669 \\
631 \\
631 \\
660 \\
660 \\
\text { Total }\end{array}$ & $\begin{array}{r}16 \\
16 \\
6 \\
6 \\
15 \\
15 \\
12 \\
12 \\
5 \\
5 \\
9 \\
9 \\
12 \\
12 \\
10 \\
10 \\
10 \\
10 \\
2 \\
2 \\
3 \\
3 \\
6 \\
6 \\
5 \\
5 \\
2 \\
2 \\
5 \\
5 \\
118 \\
118\end{array}$ & $\begin{array}{l}1 \\
2 \\
1 \\
2 \\
1 \\
2 \\
1 \\
2 \\
1 \\
2 \\
1 \\
2 \\
1 \\
2 \\
1 \\
2 \\
1 \\
2 \\
1 \\
2 \\
1 \\
2 \\
1 \\
2 \\
1 \\
2 \\
1 \\
2 \\
1 \\
2 \\
1 \\
2\end{array}$ & $\begin{array}{l}54.30 \\
53.10 \\
50.98 \\
50.79 \\
56.85 \\
54.46 \\
50.51 \\
49.55 \\
56.40 \\
52.71 \\
53.68 \\
53.83 \\
55.08 \\
53.19 \\
55.96 \\
53.29 \\
61.41 \\
58.22 \\
56.77 \\
54.45 \\
61.33 \\
59.38 \\
53.10 \\
54.09 \\
55.59 \\
54.85 \\
58.11 \\
58.44 \\
55.06 \\
55.89 \\
55.24 \\
53.81\end{array}$ & $\begin{array}{l}17.488 \\
17.093 \\
14.675 \\
14.946 \\
17.472 \\
17.218 \\
15.383 \\
15.439 \\
16.525 \\
15.862 \\
16.328 \\
16.472 \\
17.485 \\
16.821 \\
13.857 \\
13.479 \\
16.913 \\
16.646 \\
16.278 \\
15.855 \\
18.691 \\
18.958 \\
16.947 \\
17.153 \\
15.340 \\
15.539 \\
15.250 \\
15.593 \\
15.012 \\
14.745 \\
16.391 \\
16.199\end{array}$ & $\begin{array}{l}32.21 \\
32.19 \\
28.79 \\
29.43 \\
30.73 \\
31.62 \\
30.46 \\
31.16 \\
29.30 \\
30.09 \\
30.42 \\
30.60 \\
31.75 \\
31.63 \\
24.76 \\
25.29 \\
27.54 \\
28.59 \\
28.67 \\
29.12 \\
30.48 \\
31.93 \\
31.91 \\
31.71 \\
27.60 \\
28.33 \\
26.24 \\
26.68 \\
27.26 \\
26.38 \\
29.67 \\
30.10\end{array}$ \\
\hline
\end{tabular}

TABLE XXIV.-Average Weight of Eggs and Yolks in Two-Egg Cycles From Pen 1 in 1916.

\begin{tabular}{|c|c|c|c|c|c|}
\hline Hen No. & Eggs & Day & $\begin{array}{c}\text { Average Weight } \\
\text { of Eggs }\end{array}$ & $\begin{array}{c}\text { Average Weight } \\
\text { of Yolks }\end{array}$ & Percent Yolk \\
\hline 581 & 8 & 1 & 58.20 & 19.780 & 33.99 \\
\hline 581 & 8 & 2 & 56.04 & 19.012 & 33.93 \\
\hline 583 & 5 & 1 & 66.03 & 19.855 & 30.07 \\
\hline 583 & 5 & 2 & 61.76 & 20.183 & 32.68 \\
\hline 584 & 5 & 1 & 57.18 & 18.016 & 31.51 \\
\hline 584 & 5 & 2 & 55.99 & 18.021 & 32.19 \\
\hline 585 & 1 & 1 & 55.39 & 17.077 & 30.83 \\
\hline 585 & 1 & 2 & 53.90 & 16.576 & 30.75 \\
\hline 587 & 9 & 1 & 57.62 & 17.061 & 29.61 \\
\hline 587 & 9 & 2 & 54.05 & 16.598 & 30.71 \\
\hline 588 & 6 & 1 & 53.35 & 17.398 & 32.61 \\
\hline 588 & 6 & 2 & 51.10 & 16.690 & 32.66 \\
\hline 589 & 2 & 1 & 51.62 & 16.486 & 31.94 \\
\hline 589 & 2 & 2 & 50.08 & 16.370 & 32.69 \\
\hline 590 & 1 & 1 & 64.02 & 19.601 & 30.62 \\
\hline 590 & 1 & 2 & 60.82 & 18.701 & 30.75 \\
\hline
\end{tabular}


TABLE XXIV (Cont'd).-Average Weight of Eggs and Yolks in Two-Egg Cycles From Pen 1 in 1916.

\begin{tabular}{|c|c|c|c|c|c|}
\hline Hen :io. & Eggs & Day & $\begin{array}{l}\text { Arerage Weight } \\
\text { of Fggs }\end{array}$ & $\begin{array}{c}\text { Average weight } \\
\text { of Yolks }\end{array}$ & Percent Yolk \\
\hline $\begin{array}{l}591 \\
591 \\
593 \\
593 \\
595 \\
595 \\
596 \\
596 \\
\text { Total }\end{array}$ & $\begin{array}{r}5 \\
5 \\
1 \\
1 \\
7 \\
7 \\
1 \\
1 \\
51 \\
51\end{array}$ & $\begin{array}{l}1 \\
2 \\
1 \\
2 \\
1 \\
2 \\
1 \\
2 \\
1 \\
2\end{array}$ & $\begin{array}{l}64.87 \\
63.03 \\
52.38 \\
51.47 \\
62.53 \\
63.17 \\
55.86 \\
52.99 \\
59.08 \\
56.99\end{array}$ & $\begin{array}{l}17.713 \\
17.786 \\
16.583 \\
15.769 \\
19.622 \\
19.172 \\
15.876 \\
16.011 \\
18.305 \\
17.952\end{array}$ & $\begin{array}{l}27.31 \\
28.22 \\
31.66 \\
30.64 \\
31.38 \\
30.35 \\
28.42 \\
30.22 \\
30.98 \\
31.50\end{array}$ \\
\hline
\end{tabular}

TABLE XXV.-Average Weight of Eggs and Yolks in Two-Egg Cycles From Pen 2 in 1916.

\begin{tabular}{c|rr|r|r|r}
\hline \hline Hen No. & Eggs & Day & $\begin{array}{c}\text { Average Weight } \\
\text { of Eggs }\end{array}$ & $\begin{array}{c}\text { Average Weight } \\
\text { of Yolks }\end{array}$ & Percent Yolk \\
\hline 631 & 5 & 1 & 60.60 & 17.573 & 29.00 \\
631 & 5 & 2 & 54.13 & 17.493 & 32.32 \\
620 & 6 & 1 & 58.19 & 18.414 & 31.64 \\
620 & 6 & 2 & 54.46 & 17.510 & 32.15 \\
660 & 1 & 1 & 62.34 & 18.113 & 29.05 \\
660 & 1 & 2 & 54.18 & 16.870 & 31.14 \\
625 & 2 & 1 & 59.67 & 18.890 & 31.66 \\
652 & 2 & 2 & 57.81 & 18.959 & 32.80 \\
680 & 1 & 1 & 56.73 & 16.643 & 29.34 \\
680 & 1 & 2 & 53.08 & 16.676 & 31.42 \\
671 & 4 & 1 & 58.56 & 15.873 & 27.10 \\
671 & 4 & 2 & 56.18 & 15.900 & 28.30 \\
678 & 10 & 1 & 57.14 & 18.538 & 32.44 \\
678 & 10 & 2 & 54.61 & 17.748 & 32.50 \\
694 & 2 & 1 & 57.36 & 19.341 & 33.72 \\
694 & 2 & 2 & 56.39 & 18.820 & 33.37 \\
629 & 1 & 1 & 59.36 & 19.910 & 33.54 \\
629 & 1 & 2 & 54.35 & 18.741 & 34.48 \\
615 & 1 & 1 & 62.52 & 21.387 & 34.21 \\
615 & 1 & 2 & 61.67 & 21.191 & 34.36 \\
669 & 5 & 1 & 63.88 & 18.489 & 28.94 \\
669 & 5 & 2 & 64.17 & 19.333 & 30.13 \\
Total & 38 & 1 & 59.27 & 18.215 & 30.73 \\
& 38 & 2 & 56.34 & 17.876 & 31.73 \\
\hline
\end{tabular}

It may be observed from the preceding tables that the weight of the first egg and the weight of its yolk are greater than the weight of the second egg and the weight of its yolk, but the percentage of the weight of the egg that is yolk is greater in the second egg. In other words, it would appear that the yolk being the more essential part of the egg, is less affected than the white by previous production. 
The following tables give the data for the three-egg cycles:

TABLE XXVI.-Average Weight of Eggs and Yolks in Three-Egg Cycles From Pen 1 in 1915.

\begin{tabular}{|c|c|c|c|c|c|}
\hline Hen No. & Eggs & Day & $\begin{array}{c}\text { Average Weight } \\
\text { of Eggs }\end{array}$ & $\begin{array}{l}\text { Average Weight } \\
\text { of Yolks }\end{array}$ & Percent Yolk \\
\hline 581 & 1 & 1 & 53.33 & 16.988 & 31.85 \\
\hline 581 & 1 & 2 & 52.75 & 17.184 & 32.58 \\
\hline 581 & 1 & 3 & 52.43 & 16.495 & 31.46 \\
\hline 583 & 2 & 1 & 57.56 & 17.150 & 29.79 \\
\hline 583 & 2 & 2 & 55.69 & 17.717 & 31.81 \\
\hline 583 & 2 & 3 & 55.27 & 17.831 & 32.26 \\
\hline 584 & 5 & 1 & 56.13 & 16.565 & 29.51 \\
\hline 584 & 5 & 2 & 56.43 & 16.805 & 29.78 \\
\hline 584 & 5 & 3 & 55.29 & 16.277 & 29.44 \\
\hline 586 & 1 & 1 & 57.33 & 16.489 & 28.75 \\
\hline 586 & 1 & 2 & 55.64 & 16.631 & 29.89 \\
\hline 586 & 1 & 3 & 53.40 & 15.284 & 28.62 \\
\hline 587 & 2 & 1 & 49.61 & 14.923 & 30.08 \\
\hline 587 & 2 & 2 & 49.44 & 15.274 & 30.89 \\
\hline 587 & 2 & 3 & 49.05 & 14.944 & 30.47 \\
\hline 588 & 7 & 1 & 49.43 & 15.553 & 31.46 \\
\hline 588 & 7 & 2 & 48.80 & 15.257 & 31.26 \\
\hline 588 & 7 & 3 & 48.09 & 14.862 & 30.90 \\
\hline 595 & 1 & 1 & 55.63 & 17.617 & 31.67 \\
\hline 595 & 1 & 2 & 50.99 & 15.245 & 29.90 \\
\hline 595 & 1 & 3 & 55.23 & 16.952 & 30.69 \\
\hline 585 & 1 & 1 & 50.89 & 15.659 & 30.77 \\
\hline 585 & 1 & 2 & 51.21 & 15.723 & 30.70 \\
\hline 585 & 1 & 3 & 51.36 & 15.788 & 30.74 \\
\hline 592 & 1 & 1 & 49.28 & 15.713 & 31.89 \\
\hline 592 & 1 & 2 & 49.77 & 16.452 & 33.06 \\
\hline 592 & 1 & 3 & 49.85 & 16.216 & 32.53 \\
\hline \multirow[t]{3}{*}{ Total } & 21 & 1 & 52.73 & 16.110 & 30.55 \\
\hline & 21 & 2 & 52.11 & 16.097 & 30.89 \\
\hline & 21 & 3 & 51.71 & 15.795 & 30.55 \\
\hline
\end{tabular}

TABLE XXVII.-Average Weight of Eggs and Yolks in Three-Egg Cycles From Pen 2 in 1915.

\begin{tabular}{r|r|c|c|c|c}
\hline \hline Hen No. & Eggs & Day & $\begin{array}{c}\text { Average Weight } \\
\text { of Eggs }\end{array}$ & $\begin{array}{c}\text { Average Weight } \\
\text { of Yolks }\end{array}$ & Percent Yolk \\
\cline { 1 - 3 } 654 & 5 & 1 & 52.57 & 17.255 & 32.82 \\
654 & 5 & 2 & 52.17 & 17.045 & 32.67 \\
654 & 5 & 3 & 52.12 & 16.850 & 32.33 \\
634 & 6 & 1 & 51.44 & 15.533 & 30.20 \\
634 & 6 & 2 & 51.83 & 15.928 & 30.73 \\
634 & 6 & 3 & 50.21 & 15.773 & 31.41 \\
625 & 4 & 1 & 55.38 & 16.991 & 80.68 \\
625 & 4 & 2 & 55.44 & 17.526 & 31.61 \\
625 & 4 & 3 & 54.83 & 17.165 & 31.31 \\
629 & 2 & 1 & 53.13 & 16.497 & 31.04 \\
629 & 2 & 2 & 51.28 & 15.754 & 30.72 \\
629 & 2 & 3 & 51.35 & 16.156 & 31.46 \\
694 & 7 & 1 & 53.62 & 16.455 & 30.69 \\
694 & 7 & 2 & 54.93 & 16.867 & 30.70 \\
694 & 7 & 3 & 54.92 & 16.645 & 30.31 \\
\hline
\end{tabular}


TABLE XXVII (Cont'd).-Average Weight of Eggs and Yolks in Three-Egg Cycles From Pen 2 in 1915.

\begin{tabular}{|c|c|c|c|c|c|}
\hline Hen No. & Eggs & Day & $\begin{array}{l}\text { Average Weight } \\
\text { of Eggs }\end{array}$ & $\begin{array}{c}\text { Average Weight } \\
\text { of Yolks }\end{array}$ & Percent Yolk \\
\hline 678 & 1 & 1 & 57.65 & 18.424 & 31.96 \\
\hline 678 & 1 & 2 & 53.48 & 18.150 & 33.94 \\
\hline 678 & 1 & 3 & 56.17 & 18.239 & 32.47 \\
\hline 671 & 3 & 1 & 56.78 & 14.595 & 25.70 \\
\hline 671 & 3 & 2 & 54.98 & 14.514 & 26.40 \\
\hline 671 & 3 & 3 & 54.00 & 14.396 & 26.66 \\
\hline 645 & 2 & 1 & 62.19 & 17.397 & 27.97 \\
\hline 645 & 2 & 2 & 61.45 & 18.047 & 29.37 \\
\hline 645 & 2 & 3 & 60.36 & 17.017 & 28.19 \\
\hline 202 & 1 & 1 & 56.58 & 17.355 & 30.67 \\
\hline 202 & 1 & 2 & 51.88 & 17.297 & 33.34 \\
\hline 202 & 1 & 3 & 49.89 & 15.656 & 31.38 \\
\hline 620 & 1 & 1 & 53.81 & 17.320 & 32.19 \\
\hline 620 & 1 & 2 & 55.61 & 17.329 & 31.16 \\
\hline 620 & 1 & 3 & 55.29 & 17.188 & 31.09 \\
\hline 669 & 2 & 1 & 56.92 & 16.038 & 28.18 \\
\hline 669 & 2 & 2 & 57.59 & 16.431 & 28.53 \\
\hline 669 & 2 & 3 & 56.50 & 15.984 & 28.29 \\
\hline 631 & 1 & 1 & 64.08 & 16.326 & 25.48 \\
\hline 631 & 1 & 2 & 54.10 & 15.848 & 29.29 \\
\hline 631 & 1 & 3 & 54.97 & 15.607 & 28.39 \\
\hline \multirow{3}{*}{ Total } & 35 & 1 & 54.72 & 16.448 & 30.06 \\
\hline & 35 & 2 & 54.25 & 16.617 & 30.63 \\
\hline & 35 & 3 & 53.73 & 16.350 & 30.43 \\
\hline
\end{tabular}

TABLE XXVIII.-Average Weight of Eggs and Yolks in Three-Egg Cycles From Pen 1 in 1916.

\begin{tabular}{cc|ccc|c}
\hline \hline Hen No. & Eggs & Day & $\begin{array}{c}\text { Average Weight } \\
\text { of Eggs }\end{array}$ & $\begin{array}{c}\text { Average Weight } \\
\text { of Yolks }\end{array}$ & Percent Yolk \\
\cline { 1 - 6 } 581 & 7 & 1 & 59.99 & 19.512 & 32.53 \\
581 & 7 & 2 & 57.89 & 19.343 & 33.41 \\
581 & 7 & 3 & 56.52 & 18.381 & 32.52 \\
583 & 1 & 1 & 68.89 & 21.236 & 30.83 \\
583 & 1 & 2 & 62.39 & 20.236 & 32.44 \\
583 & 1 & 3 & 61.91 & 19.981 & 32.27 \\
584 & 2 & 1 & 60.32 & 18.977 & 31.46 \\
584 & 2 & 2 & 58.59 & 19.246 & 32.85 \\
584 & 2 & 3 & 56.94 & 18.008 & 31.63 \\
587 & 4 & 1 & 57.89 & 17.024 & 29.41 \\
587 & 4 & 2 & 53.45 & 16.042 & 30.01 \\
587 & 4 & 3 & 52.98 & 15.749 & 29.73 \\
591 & 1 & 1 & 68.77 & 19.164 & 27.87 \\
591 & 1 & 2 & 68.07 & 19.695 & 28.93 \\
591 & 1 & 3 & 64.27 & 18.603 & 28.94 \\
596 & 2 & 1 & 57.58 & 16.566 & 28.77 \\
596 & 2 & 2 & 56.76 & 17.075 & 30.08 \\
596 & 2 & 3 & 57.26 & 17.230 & 30.09 \\
Total & 17 & 1 & 60.29 & 18.598 & 30.85 \\
& 17 & 2 & 57.66 & 18.361 & 31.84 \\
& 17 & 3 & 56.59 & 17.689 & 31.26 \\
\hline
\end{tabular}


TABLE XXIX.-Average Weight of Eggs and Yolks in Three-Egg Cycles From Pen 2 in 1916.

\begin{tabular}{c|r|r|r|r|r}
\hline \hline Hen No. & Eggs & Day & $\begin{array}{c}\text { Average Weight } \\
\text { of Eggs }\end{array}$ & $\begin{array}{c}\text { Average Weight } \\
\text { of Yolks }\end{array}$ & Percent Yolk \\
\hline 625 & 11 & 1 & 58.73 & 19.219 & 32.72 \\
625 & 11 & 2 & 56.74 & 18.771 & 33.08 \\
625 & 11 & 3 & 55.85 & 18.442 & 33.02 \\
680 & 2 & 1 & 57.20 & 16.723 & 29.23 \\
680 & 2 & 2 & 55.46 & 16.309 & 29.41 \\
680 & 2 & 3 & 51.52 & 16.039 & 31.13 \\
671 & 2 & 1 & 55.36 & 15.333 & 27.70 \\
671 & 2 & 2 & 56.48 & 15.560 & 27.55 \\
671 & 2 & 3 & 54.80 & 14.935 & 27.25 \\
678 & 2 & 1 & 57.55 & 18.899 & 32.84 \\
678 & 2 & 2 & 57.33 & 19.090 & 33.00 \\
678 & 2 & 3 & 55.13 & 18.128 & 32.88 \\
Total & 17 & 1 & 58.01 & 18.430 & 31.77 \\
& 17 & 2 & 56.62 & 18.141 & 32.04 \\
& 17 & 3 & 55.13 & 17.709 & 32.12 \\
\hline
\end{tabular}

As the position of the egg advances in the cycle the yolk averages somewhat smaller, but with one exception the percentage of the total egg that is yolk is greater on the second day.

TABLE XXX.-Average Weight of Eggs and Yolks in Four-Egg Cycles From Pens 1 and 2 in 1915 and Pens 1 and 2 in 1916.

\begin{tabular}{|c|c|c|c|c|c|}
\hline No. Hens. & Eggs & Day & $\begin{array}{l}\text { Average Weight } \\
\text { of Eggs }\end{array}$ & $\begin{array}{l}\text { Average Weight } \\
\text { of Yolks }\end{array}$ & Percent Yolk \\
\hline & & & Pen 1, 1915. & & \\
\hline 6 & 7 & 1 & 55.35 & 16.474 & 29.76 \\
\hline 6 & 7 & 2 & 52.91 & 15.958 & 30.16 \\
\hline 6 & 7 & 3 & 53.04 & 16.345 & 30.82 \\
\hline \multirow[t]{2}{*}{6} & 7 & 4 & 53.58 & 15.989 & 29.84 \\
\hline & & & Pen 2, 1915. & & \\
\hline 4 & 7 & 1 & 54.36 & 14.818 & 27.26 \\
\hline 4 & 7 & 2 & 53.11 & 15.519 & 29.22 \\
\hline 4 & 7 & 3 & 53.81 & 15.389 & 28.60 \\
\hline \multirow[t]{2}{*}{4} & 7 & 4 & 54.06 & 15.517 & 28.70 \\
\hline & & & Pen 1, 1916. & & \\
\hline 3 & 5 & 1. & 58.23 & 17.963 & 30.85 \\
\hline 3 & 5 & 2 & 56.14 & 18.139 & 32.31 \\
\hline 3 & 5 & 3 & 54.79 & 17.889 & 32.65 \\
\hline \multirow[t]{2}{*}{3} & 5 & 4 & 54.83 & 17.796 & 32.46 \\
\hline & & & Pen 2, 1916. & & \\
\hline 2 & 7 & 1 & 58.07 & 19.087 & 32.87 \\
\hline 2 & 7 & 2 & 58.05 & 19.100 & 32.90 \\
\hline 2 & 7 & 3 & 56.90 & 18.675 & 32.82 \\
\hline 2 & 7 & 4 & 55.03 & 18.044 & 32.79 \\
\hline
\end{tabular}


TABLE XXX1.-Summary of the Results of Four-Egg Cycles.

\begin{tabular}{c|c|c|cc}
\hline \hline Eggs & Day & $\begin{array}{c}\text { Average Weight } \\
\text { of Eggs }\end{array}$ & $\begin{array}{c}\text { Average Weight } \\
\text { of Yolks }\end{array}$ & Percent Yolk \\
\hline 26 & 1 & 56.37 & 17.018 & 30.19 \\
26 & 2 & 54.97 & 17.105 & 31.12 \\
26 & 3 & 54.62 & 17.012 & 31.15 \\
26 & 4 & 54.34 & 16.763 & 30.85 \\
\hline
\end{tabular}

The average weight of the yolks does not vary greatly from one day to another, but the percentage of the total egg that is yolk seems to be somewhat larger on the second and third days. The average weight of the eggs decreases as the position in the cycle advances.

\section{CHARACTERISTICS OF EGGS LAID BY DIFFERENT HENS.}

As already pointed out it has been established by various investigators that the eggs laid by certain hens usually hatch well and produce strong, vigorcus chicks, while the eggs from other hens neither hatch well nor produce strong chicks, and it has seemed wise to study the available data with reference to the weight of the yolks and the percentage of the total egg that is yolk, as laid by the different hens under observation.

The following tables show the number of eggs laid by the different hens, with their average weight, the average weight of the yolks, and the percentage of the total egg weight that was yolk:

TABLE XXXII.-Number of Eggs, Their Average Weight, Weight of Yolks, and the Percent Yolk of Eggs Laid by the Different Hens in Pen 1 in 1915

\begin{tabular}{c|c|ccc}
\hline \hline Hen No. & No. Eggs & $\begin{array}{c}\text { Average Weight } \\
\text { of Eggs }\end{array}$ & $\begin{array}{c}\text { Average Weight } \\
\text { of Yolks }\end{array}$ & Parcent Yolk \\
\cline { 3 - 5 } \cline { 5 - 5 } 581 & 61 & 52.34 & 16.824 & 32.14 \\
582 & 56 & 50.26 & 15.615 & 31.07 \\
583 & 39 & 56.62 & 16.869 & 29.79 \\
584 & 46 & 55.70 & 16.741 & 30.06 \\
586 & 41 & 54.60 & 15.610 & 28.59 \\
587 & 54 & 47.95 & 14.104 & 29.41 \\
588 & 64 & 49.12 & 15.560 & 31.68 \\
589 & 60 & 50.16 & 14.989 & 29.88 \\
594 & 23 & 56.21 & 16.211 & 28.84 \\
535 & 60 & 57.28 & 17.663 & 30.84 \\
585 & 23 & 50.30 & 14.910 & 29.64 \\
590 & 20 & 53.84 & 14.697 & 27.30 \\
591 & 10 & 55.61 & 13.858 & 24.92 \\
592 & 19 & 48.74 & 15.682 & 32.17 \\
593 & 23 & 51.71 & 15.381 & 29.75 \\
596 & 15 & 52.07 & 14.118 & 27.11 \\
597 & 11 & 54.40 & 17.285 & 31.77 \\
Total_- & 625 & 52.44 & 15.819 & 30.17 \\
\hline
\end{tabular}


TABLE XXXIII.-Number of Eggs, Their Average Weight, Weight of Yolks, and the Percent Yolk of Eggs Laid by the Different Hens in Pen 2 in 1915.

\begin{tabular}{ccccc}
\hline Hen No. & No. Eggs & $\begin{array}{c}\text { Average Weight } \\
\text { of Eggs }\end{array}$ & $\begin{array}{c}\text { Average Weight } \\
\text { of Yolks }\end{array}$ & Fercent Yolk \\
\cline { 1 - 4 } 629 & 47 & 50.54 & 15.505 & 30.68 \\
625 & 69 & 55.73 & 17.320 & 31.08 \\
654 & 67 & 53.16 & 17.142 & 32.25 \\
634 & 47 & 51.62 & 15.489 & 30.01 \\
680 & 42 & 55.47 & 16.621 & 29.96 \\
694 & 56 & 53.51 & 16.395 & 30.64 \\
678 & 53 & 52.48 & 17.207 & 32.79 \\
671 & 66 & 54.17 & 14.003 & .25 .85 \\
645 & 47 & 60.26 & 16.732 & 27.77 \\
202 & 22 & 55.12 & 16.390 & 29.74 \\
615 & 14 & 59.32 & 18.642 & 31.43 \\
623 & 4 & 53.97 & 17.037 & 31.57 \\
620 & 32 & 52.83 & 16.650 & 31.52 \\
669 & 24 & 55.55 & 15.476 & 27.86 \\
631 & 17 & 56.34 & 15.174 & 26.93 \\
660 & 16 & 54.34 & 14.373 & 26.45 \\
617 & 9 & 53.93 & 15.860 & 29.41 \\
Total_- & 632 & 54.46 & 16.213. & 29.77 \\
\hline
\end{tabular}

TABLE XXXIV.- Number of Eggs, Their Average Weight, Weight of Yolks, and the Percent Yolk of Eggs Laid by the Different Hens in Pen 1 in 1916.

\begin{tabular}{ccc|c|c}
\hline Hen No. & No. Eggs & $\begin{array}{c}\text { Average Weight } \\
\text { of Eggs }\end{array}$ & $\begin{array}{c}\text { Average Weight } \\
\text { of Yolks }\end{array}$ & Percent Yolk \\
\hline 581 & 69 & 57.43 & 19.088 & 33.24 \\
583 & 55 & 59.87 & 18.478 & 30.86 \\
584 & 34 & 55.72 & 17.516 & 31.44 \\
585 & 12 & 53.69 & 16.738 & 31.18 \\
587 & 63 & 54.24 & 15.932 & 29.37 \\
588 & 52 & 51.35 & 16.935 & 32.98 \\
589 & 33 & 52.90 & 16.321 & 30.85 \\
590 & 8 & 61.63 & 18.239 & 29.58 \\
591 & 44 & 63.45 & 17.800 & 28.05 \\
592 & 9 & 53.46 & 18.264 & 34.16 \\
593 & 6 & 52.19 & 16.385 & 31.40 \\
595 & 26 & 60.24 & 19.051 & 31.63 \\
596 & 14 & 56.04 & 16.441 & 29.34 \\
597 & 5 & 61.42 & 20.092 & 32.71 \\
Total_. & 430 & 56.66 & 17.606 & 31.07 \\
\hline
\end{tabular}

TABLE XXXV.-Number of Eggs, Their Average Weight, Weight of Yolks, and the Percentage Yolk of Eggs Laid by the Different Hens in Pen 2 in 1916.

\begin{tabular}{c|c|c|c|c}
\hline \hline Hen No. & No. Fggs & $\begin{array}{c}\text { Average Weight } \\
\text { of Eggs }\end{array}$ & $\begin{array}{c}\text { Average Weight } \\
\text { of Yolks }\end{array}$ & Percent Yolk \\
\cline { 2 - 5 } 631 & 18 & 54.67 & 17.469 & 31.95 \\
660 & 9 & 55.20 & 16.324 & 29.57 \\
620 & 37 & 56.07 & 17.999 & 32.10 \\
625 & 68 & 57.52 & 18.753 & 32.60 \\
680 & 21 & 56.05 & 17.009 & 30.35 \\
671 & 63 & 56.57 & 15.917 & 28.14 \\
678 & 41 & 55.94 & 18.274 & 32.67 \\
694 & 51 & 55.82 & 18.573 & 33.27 \\
629 & 13 & 56.20 & 18.505 & 32.93 \\
615 & 5 & 58.92 & 20.362 & 34.56 \\
669 & 13 & 63.68 & 18.740 & 29.43 \\
Total_- & 339 & 56.64 & 17.832 & 31.48 \\
\hline
\end{tabular}


It is to be observed from the preceding tables that the average weight of the yolks of the eggs laid by the different hens varied considerably.

Hen 591 in 1915 laid ten eggs the yolks of which were separated from the whites. These eggs averaged 55.61 grams and the average weight of the yolks was 13.858 grams, or 24.92 percent of the total egg. Hen 615 laid five eggs which were examined in 1916. These averaged 58.92 grams, and the yolks 20.362 grams, or 34.56 percent of the total egg. This is a very striking and important variation and may be a reason why the chicks from certain eggs are stronger than from others.

The following tables give the weight of the eggs laid by certain hens, together with the weight of the yolks and the percent of the total egg that was yolk:

TABLE XXXVI.-Weight of Eggs, Weight of Yolks, and the Percent Yolk of Eggs Laid by Hen 581 From Pen 1 in 1915.

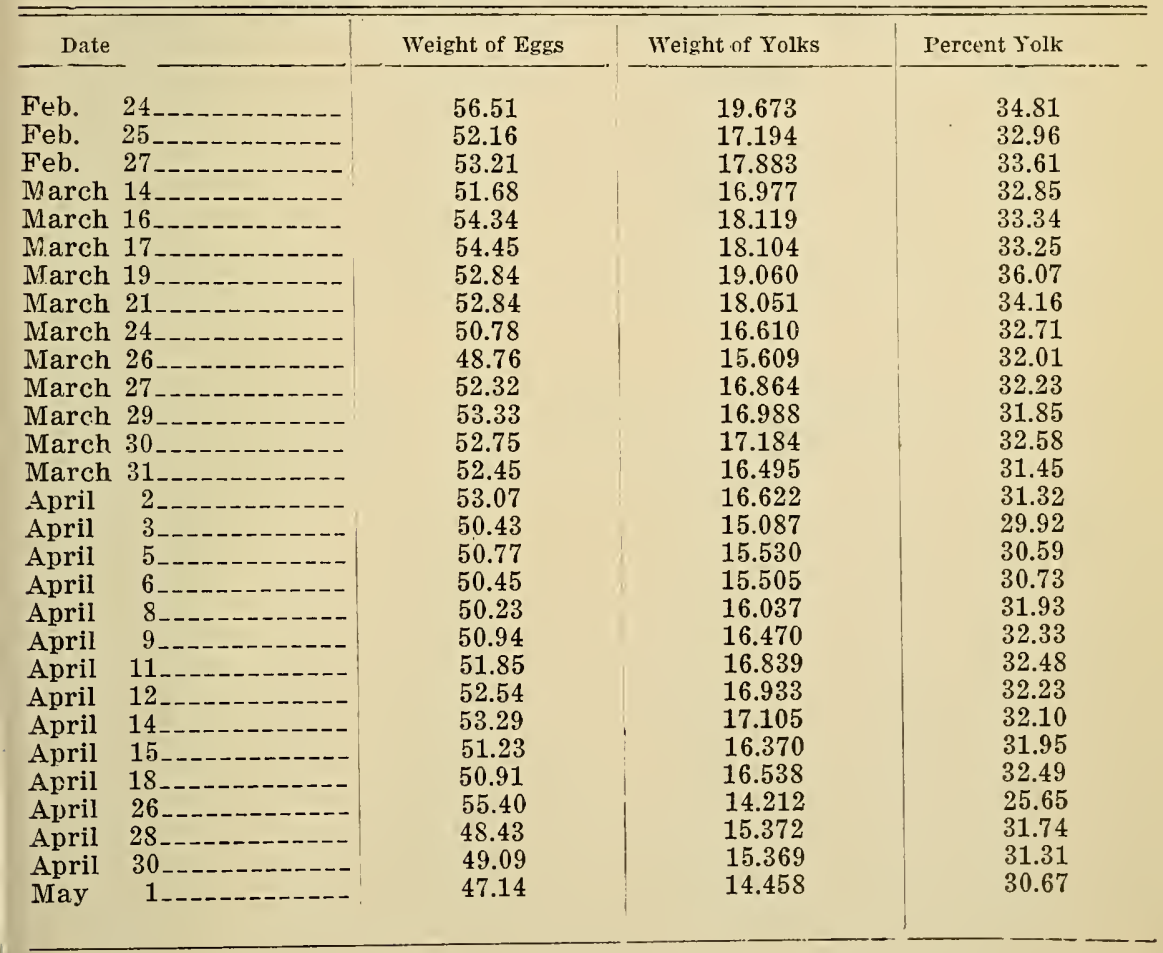


TABLE XXXVI (Cont'd).-Weight of Eggs, Weight of Yolks, and the Percent Yolk of Eggs Laid by Hen 581 From Pen 1 in 1915.

\begin{tabular}{|c|c|c|c|c|}
\hline \multicolumn{2}{|c|}{ Date } & \multirow{2}{*}{$\frac{\text { Weight of Eggs }}{48.41}$} & \multirow{2}{*}{$\frac{\text { Weight of Yolks }}{15.035}$} & \multirow{2}{*}{$\frac{\text { Percent Yolk }}{31.06}$} \\
\hline May & 3 & & & \\
\hline May & 6 & 50.11 & 15.446 & 30.83 \\
\hline May & 8 & 50.75 & 15.743 & 31.02 \\
\hline May & 10 & 48.70 & 14.612 & 30.00 \\
\hline May & $28 \ldots \ldots \ldots \ldots$ & 52.00 & 17.287 & 33.24 \\
\hline May & 30 & 57.76 & 17.866 & 30.93 \\
\hline May & $31 \ldots$ & 56.33 & 18.473 & 32.79 \\
\hline June & 1 & 57.11 & 18.122 & 31.73 \\
\hline June & 2 & 55.70 & 18.340 & 32.93 \\
\hline June & 4 & 54.07 & 18.152 & 33.57 \\
\hline June & 5._. & 54.61 & 17.542 & 32.12 \\
\hline June & $8_{-}$ & 51.79 & 16.391 & 31.65 \\
\hline June & 9 & 51.18 & 16.630 & 32.49 \\
\hline June & 11 & 51.34 & 16.078 & 31.32 \\
\hline June & 12 & 51.99 & 16.714 & 32.15 \\
\hline June & 14 & 53.38 & 17.454 & 32.70 \\
\hline June & 15 & 53.51 & 17.334 & 32.39 \\
\hline June & 17 & 50.04 & 16.316 & 32.61 \\
\hline July & 7 & 43.92 & 13.290 & 30.26 \\
\hline July & 9 & 49.69 & 16.840 & 33.89 \\
\hline July & 10 & 55.12 & 17.594 & 31.92 \\
\hline July & 12 & 54.65 & 17.732 & 32.45 \\
\hline July & 14 & 55.69 & 18.614 & 33.42 \\
\hline July & 15 & 54.50 & 17.923 & 32.83 \\
\hline July & 18 & 55.61 & 18.419 & 33.12 \\
\hline July & 19 & 53.44 & 16.876 & 31.58 \\
\hline July & 21 & 56.01 & 17.931 & 32.01 \\
\hline July & 22 & 54.73 & 17.197 & 31.42 \\
\hline July & 24 & 53.26 & 17.524 & 32.90 \\
\hline July & 25 & 53.38 & 16.640 & 31.17 \\
\hline July & 27 & 50.19 & 16.713 & 33.30 \\
\hline Aug. & 1 & 49.54 & 16.198 & 32.70 \\
\hline Aver: & re $1-0-10-10-1$ & 52.34 & 16.824 & 32.14 \\
\hline
\end{tabular}

TABLE XXXVII.-Weight of Eggs, Weight of Yolks, and the Percent Yolk of Eggs Laid by Hen 581 from Pen 1 in 1916.

\begin{tabular}{|c|c|c|c|c|}
\hline Date & & Weight of Eggs & Weight of Yolks & Percent Yolk \\
\hline March & $3 \ldots$ & 57.62 & 19.709 & 34.21 \\
\hline March & $8_{-}$ & 61.08 & 21.673 & 35.48 \\
\hline March & 9 & 58.04 & 21.241 & 36.60 \\
\hline Marcli & 11 & 60.74 & 21.210 & 34.92 \\
\hline March & 12 & 57.76 & 19.872 & 34.40 \\
\hline March & 14 & 55.55 & 18.285 & 32.92 \\
\hline March & 16 & 53.94 & 17.914 & 33.21 \\
\hline Mareh & 31 & 58.61 & 20.593 & 35.14 \\
\hline Apri! & 1 & 59.80 & 20.491 & 34.27 \\
\hline April & 3 & 58.96 & 20.302 & 34.43 \\
\hline April & 4 & 59.34 & 20.349 & 34.29 \\
\hline April & 6 & 62.13 & 20.602 & 33.16 \\
\hline Apr'il & 7 & 59.66 & 20.470 & 34.31 \\
\hline April & 8 & 58.03 & 19.057 & 32.84 \\
\hline April & 10 & 62.32 & 20.158 & 32.35 \\
\hline
\end{tabular}


TABLE XXXVII (Cont'd).-Weight of Eggs, Weight of Yolks, and the Percent Yolk of Eggs Laid by Hen 581 From Pen 1 in 1916.

\begin{tabular}{|c|c|c|c|c|}
\hline \multicolumn{2}{|l|}{ Date } & \multirow{2}{*}{$\frac{\text { Weight of Eggs }}{58.59}$} & \multirow{2}{*}{$\frac{\text { Weight of Yolks }}{19.714}$} & \multirow{2}{*}{$\frac{\text { Percent Yolk }}{33.65}$} \\
\hline April & $11 \ldots$ & & & \\
\hline April & $12 \ldots$ & 59.99 & 19.595 & 32.66 \\
\hline April & 14 & 63.95 & 20.826 & 32.57 \\
\hline April & 20 & 60.47 & 20.074 & 33.20 \\
\hline April & 21 & 58.58 & 20.139 & 34.38 \\
\hline April & $23 \ldots \ldots$ & 59.90 & 20.644 & 34.46 \\
\hline April & 24 & 56.20 & 19.132 & 34.04 \\
\hline April & 26 & 57.12 & 18.570 & 32.51 \\
\hline April & $27-\ldots$ & 55.70 & 19.000 & 34.11 \\
\hline April & 28 & 56.00 & 18.585 & 33.19 \\
\hline April & $30 \ldots$ & 56.72 & 18.716 & 33.00 \\
\hline May & 1 & 52.94 & 18.333 & 34.63 \\
\hline May. & 3 & 57.08 & 19.336 & 33.88 \\
\hline May & 4 & 57.65 & 19.335 & 33.54 \\
\hline May & 7-_- & 59.29 & 18.634 & 31.43 \\
\hline May & 8-n- & 58.83 & 19.608 & 33.33 \\
\hline May & $9--$ & 54.42 & 17.598 & 32.34 \\
\hline May & $15 \ldots \ldots-$ & 60.52 & 19.336 & 31.95 \\
\hline May & 16 & 56.44 & 19.255 & 34.12 \\
\hline May & 17 & 56.64 & 18.415 & 32.51 \\
\hline May & 19 & 59.35 & 19.558 & 32.95 \\
\hline May & 20 & 58.73 & 19.698 & 33.54 \\
\hline May & $22 \ldots-1-1-$ & 56.19 & 18.079 & 32.18 \\
\hline May & 24 & 61.27 & 19.816 & 32.34 \\
\hline May & 25 & 55.40 & 18.538 & 33.46 \\
\hline May & 26 & 54.02 & 17.406 & 32.22 \\
\hline June & 2 & 58.93 & 19.762 & 33.53 \\
\hline June & 3 & 57.65 & 19.489 & 33.81 \\
\hline June & $4 \ldots \ldots$ & 57.05 & 18.518 & 32.46 \\
\hline June & 6 & $\mathbf{5 7 . 7 4}$ & 19.343 & 33.50 \\
\hline June & $7 \ldots$ & 57.44 & 18.195 & 31.68 \\
\hline June & 8 & 55.52 & 17.785 & 32.03 \\
\hline June & 10 & 59.50 & 19.237 & 32.33 \\
\hline June & 13 & 59.05 & 18.752 & 31.76 \\
\hline June & 14 & 56.61 & 18.669 & 32.98 \\
\hline June & 15 & 53.98 & 17.700 & 32.79 \\
\hline June & $17 \ldots$ & 56.65 & 18.949 & 33.45 \\
\hline June & 18 & 56.19 & 18.241 & 32.46 \\
\hline June & $20-1-1-1-1-1$ & 55.07 & 16.886 & 30.66 \\
\hline June & $22 \ldots-----\cdots----$ & 54.07 & 17.528 & 32.42 \\
\hline June & 24 & 55.95 & 18.291 & 32.69 \\
\hline June & $26 \ldots$ & 54.68 & 17.885 & 32.71 \\
\hline June & $29 \ldots$ & 57.60 & 19.551 & 33.94 \\
\hline July & 1 & 54.88 & 18.534 & 33.77 \\
\hline July & 2 & 55.65 & 17.672 & 31.76 \\
\hline July & 4 & 55.29 & 17.880 & 32.34 \\
\hline July & 9 & 53.63 & 17.530 & 32.69 \\
\hline July & 13 & 56.57 & 18.872 & 33.36 \\
\hline July & $15 \ldots$ & 57.66 & 19.696 & 34.16 \\
\hline July & 16 & 54.76 & 18.640 & 34.04 \\
\hline July & 18 & 56.92 & 18.603 & 32.68 \\
\hline July & $20 \ldots$ & 58.94 & 19.156 & 32.50 \\
\hline July & 21 & 53.62 & 17.748 & 33.10 \\
\hline July & 23 & 55.59 & 18.121 & 32.60 \\
\hline Average & 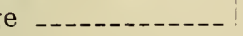 & 57.43 & 19.088 & 33.24 \\
\hline
\end{tabular}


TABLE XXXVIII.-Average Weight of Eggs, Weight of Yolks, and the Percent Yolk of Eggs Laid by Hen 588 From Pen 1 in 1915.

\begin{tabular}{|c|c|c|c|c|}
\hline \multicolumn{2}{|l|}{ Date } & Weight of Eggs & Weight of Yolks & Percent Yolk \\
\hline Feb. & $25 \ldots$ & 52.06 & 15.908 & 30.56 \\
\hline F'eb. & 27 & 52.07 & 15.803 & 30.35 \\
\hline Feb. & 28 & 50.53 & 16.078 & 31.82 \\
\hline March & 17 & 49.00 & 14.449 & 29.49 \\
\hline March & 19 & 49.52 & 15.763 & 31.83 \\
\hline March & 20 & 50.47 & 16.138 & 31.98 \\
\hline March & $22--\ldots-1-$ & 51.50 & 16.823 & 32.67 \\
\hline March & 23 & 51.48 & 17.255 & 33.52 \\
\hline March & 25 & 51.82 & 16.818 & 32.46 \\
\hline Narch & 26 & 48.39 & 15.915 & 32.89 \\
\hline March & 28 & 48.80 & 15.289 & 31.33 \\
\hline March & 30 & 47.92 & 14.891 & 31.07 \\
\hline Aprii & 12 & 49.26 & 15.522 & 31.51 \\
\hline April & $13 \ldots$ & 48.96 & 15.920 & 32.52 \\
\hline April & 14 & 48.45 & 15.631 & 32.26 \\
\hline April & 17 & 51.94 & 17.250 & 33.21 \\
\hline April & 18 & 51.54 & 17.030 & 33.04 \\
\hline April & $21 \ldots \ldots$ & 53.29 & 16.947 & 31.80 \\
\hline April & 24 & 52.67 & 17.508 & 33.24 \\
\hline April & $25_{--\ldots}$ & 51.26 & 16.318 & 31.83 \\
\hline April & $26 \ldots$ & 48.78 & 15.695 & 32.18 \\
\hline April & $27 \ldots$ & 48.66 & 15.931 & 32.74 \\
\hline April & $29 \ldots$ & 50.28 & 16.307 & 32.43 \\
\hline April & $30 \ldots$ & 51.22 & 15.945 & 31.13 \\
\hline May & 1 & 49.87 & 15.665 & 31.41 \\
\hline May & 4 & 51.19 & 15.442 & 30.17 \\
\hline May & $5 \ldots \ldots$ & 50.01 & 15.058 & 30.11 \\
\hline May & 7 & 50.50 & 15.918 & 31.52 \\
\hline May & $8^{-1}-1-0-1-0-1$ & 49.10 & 15.085 & 30.72 \\
\hline May & 9 & 46.92 & 14.171 & 30.20 \\
\hline Nay & $11 \ldots$ & 49.56 & 15.666 & 31.61 \\
\hline May & 12 & 47.30 & 14.889 & 31.48 \\
\hline May & $13 \ldots \ldots$ & 46.87 & 14.451 & 30.83 \\
\hline May & $15 \ldots$ & 49.54 & 15.705 & 31.70 \\
\hline Miay & 16 & 49.98 & 15.743 & 31.50 \\
\hline May & $2 \overline{5}_{\ldots} \ldots$ & 47.36 & 15.196 & 32.09 \\
\hline May & $27 \ldots$ & 44.02 & 14.260 & 32.39 \\
\hline June & 8........ & 47.76 & 14.734 & 30.85 \\
\hline Sune & 9 & 45.05 & 14.735 & 32.71 \\
\hline Jinne & $11 \ldots$ & 48.69 & 15.332 & 31.49 \\
\hline Tune & 12 & 47.63 & 15.289 & 32.10 \\
\hline June & $14 \ldots$ & 50.13 & 16.575 & 33.06 \\
\hline June & $15 \ldots$ & 47.06 & 15.042 & 31.96 \\
\hline June & 17 & 46.18 & 15.281 & 33.09 \\
\hline Jine & 19 & 47.67 & 14.481 & 30.38 \\
\hline June & $21_{\ldots}$ & 49.29 & 15.271 & 30.98 \\
\hline June & $2 S_{\ldots} \ldots$ & 49.03 & 15.368 & 31.34 \\
\hline June & $30 \ldots$ & 49.70 & 15.208 & 30.60 \\
\hline July & 1 & 46.84 & 15.211 & 32.47 \\
\hline July & 3 & 47.63 & 15.115 & 31.73 \\
\hline July & 5 & 48.93 & 15.702 & 32.09 \\
\hline July & $6 \ldots$ & 48.29 & 15.168 & 31.41 \\
\hline July & $8_{-}$ & 49.66 & 15.490 & 31.19 \\
\hline July & 10 & 50.73 & 16.310 & 32.15 \\
\hline July & 11 & 49.42 & 15.400 & 31.16 \\
\hline
\end{tabular}


TABLE XXXVIII (Cont'd).-Average Weight of Eggs, Weight of Yolks, and the Percent Yolk of Eggs Laid by Hen 588 From Pen 1 in 1915.

\begin{tabular}{|c|c|c|c|c|}
\hline \multicolumn{2}{|c|}{ Date } & \multirow{2}{*}{$\frac{\text { Weight of Eggs }}{51.23}$} & \multirow{2}{*}{$\frac{\text { Weight of Yolks }}{15.974}$} & \multirow{2}{*}{$\frac{\text { Percent Jolk }}{31.18}$} \\
\hline July & $13 \ldots \ldots-\ldots-n$ & & & \\
\hline July & $14 \ldots \ldots-\infty$ & 46.48 & 14.812 & 31.87 \\
\hline Iuly & 15 & 46.51 & 14.836 & 31.90 \\
\hline July & $18 \ldots \ldots$ & 48.88 & 15.006 & 30.70 \\
\hline July & $20 \ldots \ldots \ldots$ & 49.38 & 15.858 & 32.11 \\
\hline July & 21 & 48.00 & 15.104 & 31.47 \\
\hline July & 22 & 47.23 & 14.856 & 31.45 \\
\hline July & 24 & 48.10 & 15.268 & 31.74 \\
\hline July & $25 \ldots$ & 45.96 & 13.950 & 30.35 \\
\hline \multicolumn{2}{|c|}{ Average } & 49.12 & 15.560 & 31.68 \\
\hline
\end{tabular}

TABLE XXXIX.-Average Weight of Eggs, Weight of Yolks, and the Percent Yolk of Eggs Laid by Hen 588 From Pen 1 in 1916.

\begin{tabular}{|c|c|c|c|c|}
\hline \multicolumn{2}{|l|}{ Date } & \multirow{2}{*}{$\frac{\text { Weight of Eggs }}{52.64}$} & \multirow{2}{*}{ Weight of Yolks } & \multirow{2}{*}{$\frac{\text { Percent Yolk }}{32.75}$} \\
\hline Feb. & $25 \ldots$ & & & \\
\hline Feb. & 29 & 51.39 & 14.076 & 27.39 \\
\hline March & 2 & 52.11 & 16.998 & 32.62 \\
\hline March & 4 & 54.00 & 17.873 & 33.10 \\
\hline Mlarch & 6 & 50.51 & 16.628 & 32.92 \\
\hline March & $13 \ldots \ldots$ & 49.03 & 15.917 & 32.46 \\
\hline March & 15 & 54.00 & 17.678 & 32.74 \\
\hline March & 17 & 56.14 & 18.194 & 32.41 \\
\hline March & $18 \ldots$ & 51.04 & 16.734 & 32.79 \\
\hline March & $20 \ldots \ldots$ & 54.16 & 18.196 & 33.60 \\
\hline March & $21 \ldots$ & 51.75 & 16.915 & 32.63 \\
\hline March & $23_{-} \ldots-\ldots-\ldots$ & 50.97 & 16.789 & 32.94 \\
\hline March & $24 \ldots$ & 50.60 & 16.519 & 32.65 \\
\hline March & 26 & 52.01 & 17.170 & 33.01 \\
\hline March & $27 \ldots$ & 50.97 & 16.840 & 33.04 \\
\hline March & $29 \ldots$ & 53.69 & 17.523 & 32.64 \\
\hline March & $30 \ldots \ldots$ & 53.85 & 17.540 & 32.57 \\
\hline April & 1 & 50.56 & 15.854 & 31.36 \\
\hline April & $2-1--1---$ & 52.81 & 17.665 & 33.45 \\
\hline April & $3 \ldots$ & 51.02 & 16.439 & 32.22 \\
\hline April & 4 & 54.91 & 18.092 & 32.95 \\
\hline April & 6 & 55.79 & 19.363 & 34.71 \\
\hline April & 7 & 57.25 & 19.673 & 34.36 \\
\hline April & 8_- & 56.29 & 19.142 & 34.01 \\
\hline April & 9 & 53.33 & 17.457 & 32.73 \\
\hline April & $11 \ldots$ & 56.30 & 18.819 & 33.43 \\
\hline April & 12 & 52.43 & 17.608 & 33.58 \\
\hline April & $13 \ldots$ & 51.78 & 17.259 & 33.33 \\
\hline April & $20 \ldots$ & 53.10 & 18.017 & 33.93 \\
\hline April & $22 \ldots$ & 52.56 & 16.825 & 32.01 \\
\hline April & $24 \ldots$ & 53.01 & 17.359 & 32.77 \\
\hline April & 25 & 53.45 & 17.720 & 33.15 \\
\hline April & $26 \ldots$ & 51.80 & 17.014 & 32.85 \\
\hline April & 27 & 53.09 & 17.476 & 32.92 \\
\hline April & 30 & 53.15 & 16.513 & 31.07 \\
\hline Iay & 1 & 48.36 & 15.588 & 32.23 \\
\hline Iay & 3 & 51.14 & 16.582 & 32.42 \\
\hline NIay & 4 & 52.16 & 17.262 & 33.09 \\
\hline May & 5 & 50.28 & 16.859 & 33.53 \\
\hline IIay & 6 & 50.17 & 16.639 & 33.17 \\
\hline
\end{tabular}


TABLE $X X X I X$ (Cont'd).-Average Weight of Eggs, Weight of Yolks, and the Percent Yolk of Eggs Laid by Hen 588 From Pen 1 in 1916.

\begin{tabular}{|c|c|c|c|c|}
\hline \multicolumn{2}{|c|}{ Date } & \multirow{2}{*}{$\frac{\text { Weight of Eggs }}{49.97}$} & \multirow{2}{*}{$-\frac{\text { Weight of Yolks }}{16.462}$} & \multirow{2}{*}{ Percent Yolk } \\
\hline May & 9 & & & \\
\hline May & 10 & 49.66 & 16.341 & 32.91 \\
\hline May & $15 \ldots \ldots$ & 44.78 & 14.780 & 33.01 \\
\hline May & 16 & 44.92 & 14.696 & 32.72 \\
\hline May & 18 & 48.92 & 16.919 & 34.58 \\
\hline May & 19 & 47.97 & 16.152 & 33.67 \\
\hline May & 20 & 46.12 & 15.548 & 33.71 \\
\hline May & 22 & 48.73 & 16.510 & 33.88 \\
\hline May & 23 & 47.57 & 15.932 & 33.49 \\
\hline May & $24 \ldots$ & 46.36 & 15.666 & 33.79 \\
\hline June & 2 & 47.44 & 16.374 & 34.52 \\
\hline June & 4 & 44.11 & 15.197 & 34.45 \\
\hline Aver & e - & 51.35 & 16.935 & 32.98 \\
\hline
\end{tabular}

TABLE XL.-Average Weight of Eggs, Weight of Yolks, and the Percent Yolk of Eggs Laid by Hen 625 From Pen 2 in 1915.

\begin{tabular}{|c|c|c|c|c|}
\hline \multicolumn{2}{|l|}{ Date } & Weight of Eggs & Weight of Yolks & Percent Yolk \\
\hline Feb. & 28 & 53.59 & 15.711 & 29.32 \\
\hline March & 1 & 54.17 & 16.179 & 29.87 \\
\hline March & $3_{-\ldots-\ldots-1}$ & 55.32 & 17.053 & 30.83 \\
\hline March & 4 & 56.66 & 17.892 & 31.58 \\
\hline March & 5 & 56.19 & 17.521 & 31.18 \\
\hline March & 7....---- & 57.70 & 17.597 & 30.50 \\
\hline March & $8-\ldots-0-1$ & 54.34 & 17.273 & 31.79 \\
\hline March & 10 & 55.38 & 17.647 & 31.87 \\
\hline March & $11 \ldots$ & 53.15 & 17.162 & 32.29 \\
\hline March & 13 & 55.65 & 17.268 & 31.03 \\
\hline March & 16 & 54.58 & 16.236 & 29.75 \\
\hline March & $17 \ldots \ldots$ & 53.78 & 16.798 & 31.24 \\
\hline March & 19 & 56.14 & 16.432 & 29.27 \\
\hline March & 20 & 55.01 & 16.812 & 30.56 \\
\hline March & $22--\ldots-n-1$ & 56.93 & 17.756 & 31.19 \\
\hline March & 23 & 57.33 & 17.685 & 30.85 \\
\hline March & $27---1--n$ & 57.70 & 17.811 & 30.87 \\
\hline March & $29--------\cdots-$ & 59.31 & 18.296 & 30.85 \\
\hline March & $30 \ldots$ & 57.74 & 18.008 & 31.19 \\
\hline April & 1 & 58.64 & 17.859 & 30.46 \\
\hline April & 2 & 57.43 & 17.969 & 31.29 \\
\hline April & 4 & 58.73 & 18.719 & 31.87 \\
\hline April & 5 & 57.22 & 18.593 & 32.49 \\
\hline April & $7 \ldots \ldots-\infty-1-$ & 53.76 & 17.625 & 32.79 \\
\hline April & 8 & 47.77 & 16.385 & 34.30 \\
\hline Aporil & $11---1----$ & 54.45 & 16.376 & 30.08 \\
\hline April & 14 & 55.56 & 17.120 & 30.81 \\
\hline April & 15 & 53.95 & 16.821 & 31.18 \\
\hline April & 17 & 58.03 & 17.911 & 30.87 \\
\hline April & 18 & 57.40 & 18.844 & 32.83 \\
\hline April & 21 & 57.36 & 18.668 & 32.54 \\
\hline April & $22 \ldots \ldots$ & 55.89 & 18.216 & 32.59 \\
\hline A pril & $23 \ldots \ldots+\ldots$ & 56.37 & 17.733 & 31.46 \\
\hline April & $25_{-}$ & 53.85 & 16.866 & 31.32 \\
\hline April & $27----------$ & 54.69 & 16.420 & 30.02 \\
\hline April & $28 \ldots----------$ & 52.43 & 16.370 & 31.22 \\
\hline
\end{tabular}


TABLE XL (Cont'd).-Average Weight of Eggs, Weight of Yolks, and the Percent Yolk of Eggs Laid by Hen 625 From Pen 2 in 1915.

\begin{tabular}{|c|c|c|c|c|c|}
\hline \multicolumn{2}{|l|}{ Date } & \multirow{2}{*}{$\frac{\text { Weight of Eggs }}{53.52}$} & ' & \multirow{2}{*}{$\frac{\text { Weight of Yolks }}{16.143}$} & \multirow{2}{*}{ Percent Yolk } \\
\hline April & $30 \ldots$ & & & & \\
\hline May & 1 & 53.12 & & 16.079 & 30.27 \\
\hline May & $2 \ldots-0-1-0-1$ & 51.11 & & 15.889 & 31.09 \\
\hline May & 4 & 53.29 & & 16.057 & 30.13 \\
\hline May & 5 & 50.42 & & 15.399 & 30.54 \\
\hline May & $7 \ldots \ldots$ & $54.5 \mathrm{~S}$ & & 15.992 & 29.30 \\
\hline May & 9 & 54.34 & & 15.808 & 29.09 \\
\hline May & $11 \ldots$ & 55.09 & & 16.574 & 30.09 \\
\hline May & 12 & 56.02 & & 16.864 & 30.10 \\
\hline May & $28 \ldots$ & 55.33 & & 16.100 & 29.10 \\
\hline May & 29 & 56.11 & & 17.919 & 31.94 \\
\hline May & 30 & 55.66 & & 17.517 & 31.47 \\
\hline June & 1 & 59.73 & & 18.668 & 31.25 \\
\hline June & 3 & $57.08 \cdot$ & & 17.767 & 31.13 \\
\hline June & 10 & 54.13 & & 16.349 & 30.20 \\
\hline June & $20 \ldots$ & 55.21 & & 15.627 & 28.30 \\
\hline June & 21 & 54.02 & & 17.236 & 31.91 \\
\hline June & $23 \ldots \ldots-\ldots$ & 56.01 & & 17.954 & 32.05 \\
\hline June & 24 & 55.11 & & 17.188 & 31.19 \\
\hline July & $2 \ldots-\ldots$ & 55.20 & & 17.295 & 31.33 \\
\hline July & 5 & 54.78 & & 17.542 & 32.02 \\
\hline July & 7 & 53.82 & & 16.104 & 29.92 \\
\hline JuIy & $16 \ldots$ & 53.37 & & 15.804 & 29.61 \\
\hline July & $18 \ldots$ & 58.27 & & 17.833 & 30.60 \\
\hline July & 19 & 58.66 & & 18.816 & 32.08 \\
\hline July & $20 \ldots$ & 58.44 & & 18.758 & 32.10 \\
\hline July & $21 \ldots$ & 60.49 & & 19.117 & 31.60 \\
\hline July & $23 \ldots \ldots-n$ & 63.60 & & 20.026 & 31.86 \\
\hline July & $24 \ldots \ldots$ & 54.64 & & 16.988 & 31.09 \\
\hline July & $26 \ldots$ & 59.13 & & 18.658 & 31.55 \\
\hline July & $27 \ldots-\ldots-$ & 57.75 & & 18.791 & 32.54 \\
\hline July & 29 & 58.19 & & 18.505 & 31.80 \\
\hline Aug. & 1 & 55.12 & & 18.059 & 32.76 \\
\hline Averag & e - - - & 55.73 & 1 & 17.320 & 31.08 \\
\hline
\end{tabular}

TABLE XLI.-Average Weight of Eggs, Weight of Yolks, and the Percent Yolk of Eggs Laid by Hen 625 From Pen 2 in 1916.

\begin{tabular}{|c|c|c|c|c|}
\hline \multicolumn{2}{|c|}{ Date } & Weight of Eggs & Weight of Yolks & Percent Yolk \\
\hline March & 16 & 59.19 & 17.382 & 29.37 \\
\hline March & 18 & 60.58 & 18.933 & 31.25 \\
\hline March & $20 \ldots$ & 61.68 & 19.301 & 31.29 \\
\hline March & 22 & 60.18 & 18.522 & 30.78 \\
\hline March & 23 & 57.90 & 18.793 & 32.46 \\
\hline March & $28 \ldots$ & 59.21 & 18.622 & 31.45 \\
\hline April & 1 & 60.51 & 19.431 & 32.11 \\
\hline April & 3 & 60.98 & 19.020 & 31.19 \\
\hline April & 4 & 59.28 & 18.375 & 31.00 \\
\hline April & 5 & 57.28 & 17.245 & 30.11 \\
\hline April & 8 & 58.28 & 18.219 & 31.26 \\
\hline April & 9 & 56.99 & 17.671 & 31.01 \\
\hline April & 11 & 59.69 & 18.871 & 31.62 \\
\hline April & 12 & 58.15 & 18.636 & 32.05 \\
\hline April & 13 & 58.25 & 18.649 & 32.02 \\
\hline April & 14 & 56.47 & 17.452 & 30.91 \\
\hline April & 21 & 60.89 & 19.719 & 32.38 \\
\hline
\end{tabular}


TABLE XLI (Cont'd).-Average Weight of Eggs, Weight of Yolks, and the Percent Yolk of Eggs Laid by Hen 625 From Pen 2 in 1916.

\begin{tabular}{|c|c|c|c|c|}
\hline \multicolumn{2}{|l|}{ Date } & Weight of Eggs & Weight of Yolks & Percent Yolk \\
\hline April & $23 \ldots$ & 57.85 & 19.276 & 28.41 \\
\hline April & 25 & 61.09 & 19.509 & 31.94 \\
\hline April & 26 & 58.70 & 19.141 & 32.61 \\
\hline April & $27 \ldots \ldots$ & 60.44 & 19.232 & 31.82 \\
\hline April & 29 & 60.86 & 19.650 & 32.29 \\
\hline April & $30-\ldots-\ldots$ & 59.73 & 19.915 & 33.34 \\
\hline May & 1 & 57.62 & 18.725 & 32.50 \\
\hline May & $2 \ldots \ldots-\cdots$ & 57.91 & 18.942 & 32.71 \\
\hline May & 4 & 60.29 & 19.584 & 32.48 \\
\hline May & 6 & 57.27 & 18.667 & 32.59 \\
\hline May & 8_----------- & 59.16 & 19.259 & 32.55 \\
\hline May & 9 & 57.72 & 19.124 & 33.13 \\
\hline May & 15 & 53.48 & 18.013 & 33.68 \\
\hline May & 17 & 57.74 & 18.581 & 32.18 \\
\hline May & $22 \ldots \ldots-\ldots \ldots$ & 57.53 & 18.744 & 32.58 \\
\hline Mav & $23 \ldots \ldots \ldots$ & 57.00 & 18.758 & 32.91 \\
\hline May & $24 \ldots \ldots$ & 55.24 & 18.020 & 32.62 \\
\hline May & 25 & 54.72 & 17.834 & 32.59 \\
\hline June & 3 & 54.33 & 18.434 & 33.93 \\
\hline June & 5 & 58.41 & 19.169 & 32.82 \\
\hline June & 6 & 56.92 & 19.054 & 33.48 \\
\hline June & 7 & 56.75 & 18.801 & 33.13 \\
\hline June & 10 & 59.24 & 19.062 & 32.18 \\
\hline June & $11-\ldots-1-0-1$ & 57.31 & 19.316 & 33.70 \\
\hline June & 12 & 56.97 & 19.171 & 33.65 \\
\hline June & 14 & 58.52 & 19.474 & 33.28 \\
\hline June & $15 \ldots$ & 56.59 & 18.887 & 33.37 \\
\hline June & 16 & 56.78 & 18.763 & 33.04 \\
\hline June & $18 \ldots$ & 57.58 & 18.758 & 32.58 \\
\hline June & 19 & 57.33 & 18.997 & 33.14 \\
\hline Juse & 20 & 55.77 & 18.483 & 33.14 \\
\hline June & 22 & 60.87 & 20.530 & 33.73 \\
\hline June & 23 & 54.07 & 17.476 & 32.32 \\
\hline June & 24 & 53.67 & 18.030 & 33.59 \\
\hline June & $27 \ldots$ & 57.88 & 19.432 & 33.57 \\
\hline June & 28 & 55.74 & 18.710 & 33.57 \\
\hline June & 29 & 54.05 & 18.566 & 34.35 \\
\hline July & 1 & 58.46 & 19.354 & 33.11 \\
\hline July & 2 & 55.38 & 18.417 & 33.26 \\
\hline July & $3 \ldots-\ldots-1$, & 53.90 & 18.332 & 34.01 \\
\hline July & 5 & 57.93 & 18.970 & 32.00 \\
\hline July & 9 & 56.37 & 18.606 & 33.01 \\
\hline July & $10 \ldots$ & 57.02 & 19.308 & 33.86 \\
\hline July & $11+1-1$, & 54.25 & 18.123 & 33.41 \\
\hline July & 13 & 58.41 & 19.689 & 33.71 \\
\hline July & $14 \ldots$ & 54.69 & 18.439 & 33.72 \\
\hline July & $17 \ldots$ & 56.60 & 18.494 & 32.67 \\
\hline July & 18 & 55.75 & 18.807 & 33.73 \\
\hline July & $19 \ldots$ & 54.52 & 18.119 & 33.23 \\
\hline July & $22 \ldots \ldots$ & 56.51 & 18.553 & 32.83 \\
\hline July & $23 \ldots-n-\ldots--$ & 53.11 & 17.098 & 32.19 \\
\hline Averag & be --n-..- & 57.52 & 18.753 & 32.60 \\
\hline
\end{tabular}


TABLE XLII.-Average Weight of Eggs, Weight of Yolks, and the Percent Yolk of Eggs Laid by Hen 694 From Pen 2 in 1915.

\begin{tabular}{|c|c|c|c|c|}
\hline \multicolumn{2}{|l|}{ Date } & \multirow{2}{*}{$\frac{\text { Weight of Eggs }}{51.02}$} & \multirow{2}{*}{$\frac{\text { Weight of Folks }}{15.553}$} & \multirow{2}{*}{$-\frac{\text { Percent Yolk }}{30.48}$} \\
\hline March & 3-_- & & & \\
\hline March & 7 & 51.58 & 16.101 & 31.22 \\
\hline March & 10 & 50.70 & 15.719 & 31.00 \\
\hline March & 15 & 53.91 & 17.296 & 32.08 \\
\hline March & 17 & 57.88 & 17.796 & 30.75 \\
\hline March & 18 & 57.68 & 17.931 & 31.09 \\
\hline March & 20 & 59.01 & 18.886 & 32.00 \\
\hline March & $21 \ldots \ldots$ & 57.72 & 17.660 & 30.59 \\
\hline March & $23 \ldots \ldots-n----$ & 57.35 & 17.975 & 31.34 \\
\hline March & 24 & 56.14 & 17.721 & 31.57 \\
\hline March & $27 \ldots-\ldots-1$ & 57.72 & 18.197 & 31.53 \\
\hline March & $28 \ldots \ldots-\ldots$ & 56.04 & 17.173 & 30.64 \\
\hline March & $29-\ldots-1-1-$ & 57.90 & 18.507 & 31.96 \\
\hline March & $31 \ldots-\ldots-\ldots$ & 57.10 & 17.989 & 31.50 \\
\hline April & 1 & 58.01 & 18.343 & 31.62 \\
\hline April & $2----------$ & 59.30 & 17.481 & 29.48 \\
\hline April & 4 & 53.71 & 16.715 & 31.12 \\
\hline April & $5--1---1-$ & 54.13 & 16.866 & 31.16 \\
\hline April & $7 \ldots$ & 52.83 & 16.642 & 31.50 \\
\hline April & 8_....... & 54.24 & 16.232 & 29.93 \\
\hline April & 10 & 56.96 & 16.550 & 29.06 \\
\hline April & $11-\ldots$ & 52.94 & 16.005 & 30.23 \\
\hline April & 13 & 52.09 & 15.121 & 29.03 \\
\hline April & $14-\ldots$ & 53.08 & 15.940 & 30.03 \\
\hline April & $15 \ldots$ & 54.54 & 15.854 & 29.07 \\
\hline April & $17--\ldots$ & 52.10 & 16.150 & 31.00 \\
\hline April & 19 & 53.48 & 15.891 & 29.71 \\
\hline April & 21 & 53.54 & 16.748 & 31.28 \\
\hline April & $22--\ldots-n---$ & 54.85 & 16.441 & 29.97 \\
\hline April & $23 \ldots \ldots \ldots-\ldots$ & 52.45 & 15.604 & 29.75 \\
\hline April & 25 & 52.74 & 15.892 & 30.13 \\
\hline May & 9 & 47.16 & 13.168 & 27.92 \\
\hline May & 11 & 49.63 & 15.054 & 30.33 \\
\hline May & $12 \ldots-\ldots$ & 51.69 & 15.892 & 30.74 \\
\hline May & 14 & 51.06 & 16.022 & 31.38 \\
\hline May & $15 \ldots$ & 53.49 & 16.580 & 31.00 \\
\hline May & $16 \ldots$ & 54.81 & 16.254 & 29.65 \\
\hline May & 25 & 52.88 & 16.244 & 30.72 \\
\hline May & 26 & 53.19 & 15.581 & 29.29 \\
\hline May & $28 \ldots$ & 53.83 & 15.526 & 28.84 \\
\hline May & 29 & 53.64 & 15.834 & 29.52 \\
\hline May & 30 & 50.17 & 14.456 & 28.81 \\
\hline June & 1 & 52.73 & 15.550 & 29.49 \\
\hline June & 25 & 51.38 & 15.748 & 30.65 \\
\hline June & 26 & 49.95 & 15.913 & 31.86 \\
\hline June & $27 \ldots$ & 52.83 & 17.152 & 32.47 \\
\hline June & $2 S_{-}$ & 49.98 & 16.517 & 33.05 \\
\hline June & $30 \ldots$ & 49.27 & 16.230 & 32.94 \\
\hline July & 6 & 52.23 & 14.591 & 27.94 \\
\hline July & 8-- & 49.62 & 13.620 & 27.45 \\
\hline July & 9 & 49.81 & 14.462 & 29.03 \\
\hline July & $26 \ldots-\ldots-n-1$ & 50.61 & 15.445 & 30.52 \\
\hline July & $27-0+0$ & 53.10 & 17.622 & 33.19 \\
\hline July & 29 & 50.03 & 15.579 & 31.14 \\
\hline July & 30 & 55.39 & 17.760 & 32.06 \\
\hline July & 31 & 55.26 & 18.356 & 33.22 \\
\hline Averag & 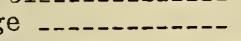 & 53.51 . & 16.395 & 30.64 \\
\hline
\end{tabular}


TABLE XLIII.-Average Weight of Eggs, Weight of Yolks, and the Percent Yolk of Eggs Laid by Hen 694 From Pen 2 in 1916.

\begin{tabular}{|c|c|c|c|c|}
\hline \multicolumn{2}{|l|}{ Date } & \multirow{2}{*}{$\frac{\text { Weight of Eggs }}{56.13}$} & \multirow{2}{*}{$\frac{\text { Weight of Yolins }}{19.654}$} & \multirow{2}{*}{$\frac{\text { Percent Yolk }}{35.01}$} \\
\hline Feb. & $27 \ldots$ & & & \\
\hline March & 2 & 62.26 & 21.545 & 34.61 \\
\hline March & 4 & 60.28 & 18.024 & 29.90 \\
\hline March & 7 & 59.53 & 20.861 & 35.04 \\
\hline March & 10 & 60.13 & 20.032 & 33.31 \\
\hline March & 12 & 62.03 & 21.065 & 33.96 \\
\hline March & $15 \ldots$ & 59.70 & 20.201 & 33.84 \\
\hline March & 16 & 57.80 & 19.762 & 34.19 \\
\hline March & 18 & 60.77 & 20.472 & 33.69 \\
\hline March & 28 & 60.03 & 20.060 & 33.42 \\
\hline March & 30 & 60.91 & 20.000 & 32.84 \\
\hline April & 2 & 59.55 & 19.092 & 32.06 \\
\hline April & 3. & 59.20 & 19.852 & 33.53 \\
\hline April & 4 & 60.83 & 19.014 & 31.26 \\
\hline April & 5 & 55.48 & 18.099 & 32.62 \\
\hline April & 7 & 59.80 & 19.582 & 32.75 \\
\hline April & $8^{-}-1-0-0-0-0$ & 58.00 & 19.125 & 32.97 \\
\hline April & 9 & 56.70 & 18.927 & 33.38 \\
\hline April & 10 & 51.61 & 17.627 & 34.15 \\
\hline April & 12 & 55.54 & 17.822 & 32.09 \\
\hline April & 14 & 55.54 & 17.582 & 31.66 \\
\hline April & 20 & 51.62 & 16.146 & 31.28 \\
\hline April & 21 & 50.43 & 16.329 & 32.38 \\
\hline May & 3 & 51.94 & 16.780 & 32.31 \\
\hline May & 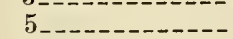 & 51.54 & 16.903 & 32.80 \\
\hline May & 6 & 53.98 & 17.991 & 33.33 \\
\hline May & 7 & 53.38 & 18.426 & 34.52 \\
\hline May & 8 & 54.04 & 18.149 & 33.58 \\
\hline May & 9 & 54.42 & 18.236 & 33.51 \\
\hline May & 10 & 53.55 & 17.631 & 32.92 \\
\hline May & 16 & 53.19 & 18.665 & 35.09 \\
\hline May & 17 & 53.01 & 18.062 & 34.07 \\
\hline May & 21 & 54.02 & 17.594 & 32.57 \\
\hline May & 22 & 52.04 & 16.701 & 32.09 \\
\hline May & 23 & 55.01 & 16.134 & 29.33 \\
\hline June & 13 & 53.80 & 18.632 & 27.51 \\
\hline June & 14 & 53.13 & 18.205 & 34.27 \\
\hline June & 15 & 51.16 & 17.884 & 34.96 \\
\hline June & 16 & 52.27 & 18.419 & 35.24 \\
\hline June & 17 & 53.92 & 19.146 & 35.51 \\
\hline June & $19-0-0-1$ & 54.98 & 19.464 & 35.40 \\
\hline June & 20 & $57: 75$ & 18.978 & 32.86 \\
\hline June & 21 & 57.94 & 20.166 & 34.80 \\
\hline June & 22 & 59.42 & 20.261 & 34.10 \\
\hline June & 24 & 55.02 & 18.480 & 33.59 \\
\hline June & 25 & 54.98 & 17.878 & 32.52 \\
\hline June & 27 & 56.74 & 17.610 & 31.04 \\
\hline June & 29 & 54.09 & 18.206 & 33.66 \\
\hline June & 30 & 56.55 & 18.439 & 32.61 \\
\hline July & 1 & 51.69 & 17.224 & 33.32 \\
\hline July & $20-0-0-1$ & 49.63 & 16.096 & 32.43 \\
\hline Averag & re & 55.82 & 18.573 & 32.27 \\
\hline
\end{tabular}


The preceding tables show that the eggs laid by individual hens vary considerably in respect to their weight, the weight of the yolk, and the percent of the total egg weight that is yolk. To what extent these variations are due to excitement, digestive disturbances, fluctuations in temperature, or other causes is impossible to determine from the available data, and should be made the subject of further inquiry.

\section{CONCLUSIONS.}

(1). The heavier the egg, the heavier the yolk.

(2). The heavier the egg, the smaller is the total percentage of the egg that is yolk.

(3). When eggs are laid in cycles the first egg in the cycle is usually the heaviest, the other eggs decreasing in weight according to their position in the cycle.

(4). The weight of the yolk usually decreases according to the position of the egg in the cycle.

(5). In general, the first egg in all cycles has a lower percentage of total egg that is yolk than has any of the other eggs.

(6). The eggs laid by individual hens not only vary widely in regard to their average weight and the average weight of their yolks, but the average percentage of the total egg that is yolk also raries widely.

(7). The results indicate that the presence of a considerable amount of animal protein in the ration for laying hens tends to weaken the vitelline membrane.

(8). The eggs and yolks from the wheat fed fowls averaged somewhat heavier than the eggs and yolks from the corn fed fowls.

(9). In 1915 with the smaller amount of scrap in the ration the percentage of the total egg that was yolk was greater in the eggs from the corn fed fowls; but in 1916 with a larger amount of scrap, the percentage was smaller than in the eggs from the wheat fed fowls.

(10). During the second year of the test, the weight of eggs and yolks and the percentage of the total egg that was yolk, were greater than during the first year. 


6 